\title{
Rainfall and Flooding in Coastal Tourist Areas of the Canary Islands (Spain)
}

\author{
Abel López Díez ${ }^{1}$, Pablo Máyer Suárez ${ }^{2, *}$, Jaime Díaz Pacheco ${ }^{1}$ and Pedro Dorta Antequera ${ }^{1}$ \\ 1 University of La Laguna (ULL), 38320 San Cristóbal de La Laguna, Tenerife, Spain; \\ alopezd@ull.edu.es (A.L.D.); jdiazpac@ull.edu.es (J.D.P.); pdorta@ull.edu.es (P.D.A.) \\ 2 Physical Geography and Environment Group, Institute of Oceanography and Global Change (IOCAG), \\ University of Las Palmas de Gran Canaria (ULPGC), 35214 Telde, Gran Canaria, Spain \\ * Correspondence: pablo.mayer@ulpgc.es
}

Received: 19 November 2019; Accepted: 11 December 2019; Published: 13 December 2019

\begin{abstract}
Coastal spaces exploited for tourism tend to be developed rapidly and with a desire to maximise profit, leading to diverse environmental problems, including flooding. As the origin of flood events is usually associated with intense precipitation episodes, this study considers the general rainfall characteristics of tourist resorts in two islands of the Canary Archipelago (Spain). Days of intense rainfall were determined using the 99th percentile (99p) of 8 daily precipitation data series. In addition, the weather types that generated these episodes were identified, the best-fitting distribution functions were determined to allow calculation of probable maximum daily precipitation for different return periods, and the territorial and economic consequences of flood events were analysed. The results show highly irregular rainfall, with $99 \mathrm{p}$ values ranging $50-80 \mathrm{~mm}$. The weather types associated with 49 days of flooding events were predominantly cyclonic and hybrid cyclonic. The Log Pearson III distribution function best fitted the data series, with a strong likelihood in a 100 -year return period of rainfall exceeding $100 \mathrm{~mm}$ in a $24 \mathrm{~h}$ period. However, values below 30 $\mathrm{mm}$ have already resulted in significant flood damage, while intense rainfall events in the period 1998-2016 saw over 11.5 million euros paid out in damages for insured goods. Such flood-induced damages were found to be caused more by inadequate urban planning than by rainfall intensity.
\end{abstract}

Keywords: intense rainfall; floods; tourism; weather types; Canary Islands

\section{Introduction}

Numerous research studies have investigated the role of meteorological conditions when deciding upon a site for a tourist establishment. It is clear from these studies that although weather conditions are a fundamental consideration when determining the site for a new tourist establishment, on many occasions no assessment is made of the possibility of the occurrence of extreme weather events nor of their potential consequences [1-3]. Various works simply treat the risk of flooding as an emergency episode which needs to be properly managed, without considering territorial planning as an element of prevention [4]. In general terms, it has been found that tourist developments cause substantial changes to the territory as the result of land use modifications. In this respect, a 'sun and beach' type tourist development that has been inappropriately planned will have negative impacts on the coastal environment [1,5-7], and, consequently, on the quality of the tourism offer.

An extensive number of studies have also been published, from various perspectives and considering all corners of the globe, on the effects of extreme rainfall in consolidated urban spaces, especially with respect to the generation of flooded areas. However, there are relatively few studies which have tackled this issue with respect to coastal tourist areas. Moreover, most of these have focussed on assessing the flooding processes that may arise as the result of sea level rise in a context 
of global climate change, with discussions on the possible measures that should be taken along the coastline (protective measures and modifications to infrastructure and equipment, etc.) to counter rough sea weather [8,9].

Other aspects that have been dealt with in the literature include the natural fragility of islands and their special vulnerability in the face of climate change $[10,11]$. As a result, the managers of tourist establishments find themselves obliged to work in this respect on adaptation measures. In this context, one of the objectives of the EU's Strategy on Adaptation to Climate Change [12] is to promote such adaptation in vulnerable sectors. Further details in this respect are explored in Spain's III Work Programme-2014/2020 in the National Climate Change Adaptation Plan [13], which determines the need to establish regionalised climate change scenarios specifically for islands which contemplate, among other questions, strategies for coastal adaptation to counter the effects of climate change.

Again, there are very few studies with specific reference to Spain which have analysed flood risk management in coastal tourist areas. Of those that have been published, perhaps the most noteworthy have considered the case of Spain's Levante coast, underlining the need for cooperation between different administrations in an environment which has experienced intensive tourist development in both time and form [6,14-16].

Finally, it is important to stress that floods can result in a loss of competitiveness in tourist destinations as the result of safety guarantees at such places being put in doubt. This is one more reason why the risk of such events needs to be reduced and tourist destinations subjected to appropriate planning ordinances [17]. Along these lines, the present study aims to contribute to the field of tourism climatology through an analysis and discussion of floods and flooding in the Canary Islands (Spain), one of the world's most tourism-dominated archipelagos. Given that, in the meteorological context of the Canary Islands, these floods are caused by episodes of intense rainfall, the main objectives of this research study have been as follows: (i) to characterise rainfall, especially in terms of its risk factors; (ii) to find and select intense rainfall episodes; (iii) to identify the weather types that have generated these episodes; (iv) to determine the distribution function of extreme variables that best fits the series of daily rainfall in order to establish the probable maximum precipitation values for different return periods; and (v) to assess the socioeconomic and territorial impact of extreme rainfall episodes on the selected tourist spaces. This latter assessment is a fundamental objective of the research work in view of the fact that, as explained in greater detail below, these spaces are the economic engine of this archipelago.

\section{Context and Sphere of Study}

In 2017, according to data from the United Nations World Tourism Organisation (UNWTO) [18], Spain welcomed 81.8 million tourists, more than any other country in the world except France (86.9 millon), and was also second in terms of income from tourism ( $€ 58,620$ million). After Catalonia, the autonomous region of Spain which received most visitors was the Canary Islands. According to data published by the Canary Institute of Statistics [19], a total of 15,559,788 tourists visited the islands in 2018 (including tourists both from other countries and from other autonomous regions of Spain), a value similar to the three preceding years. It should also be noted that, in terms of its economic impact, tourism in the Canary Islands is responsible for $30 \%$ of Gross Domestic Product (GDP), $40 \%$ of employment, and $35 \%$ of all taxes collected [20]. In Spain, similar percentages are only found for the Balearic Islands [21]. Of all the tourists who visited the islands, $67 \%$ went to Tenerife or Gran Canaria, with most of them staying in the tourist resorts of the south and south-west of the two islands. That is, more than half the visitors to the islands stayed in areas which were selected as study areas for the purposes of the present work (Figure 1), namely the tourist centres situated in the municipalities of Arona and Adeje in Tenerife and San Bartolomé de Tirajana and Mogán in Gran Canaria (Figure 1). In total, these four spaces only occupy $27.7 \mathrm{~km}^{2}$ and their urban development is concentrated between the coast and a height of $180 \mathrm{~m}$ above sea level. These spaces are among the highest in terms of annual hours of sunshine and the lowest in terms of rainfall, not only in the Canary 
Islands but across the whole of Spain. It is, of course, precisely these climate conditions that are so attractive for European tourism.

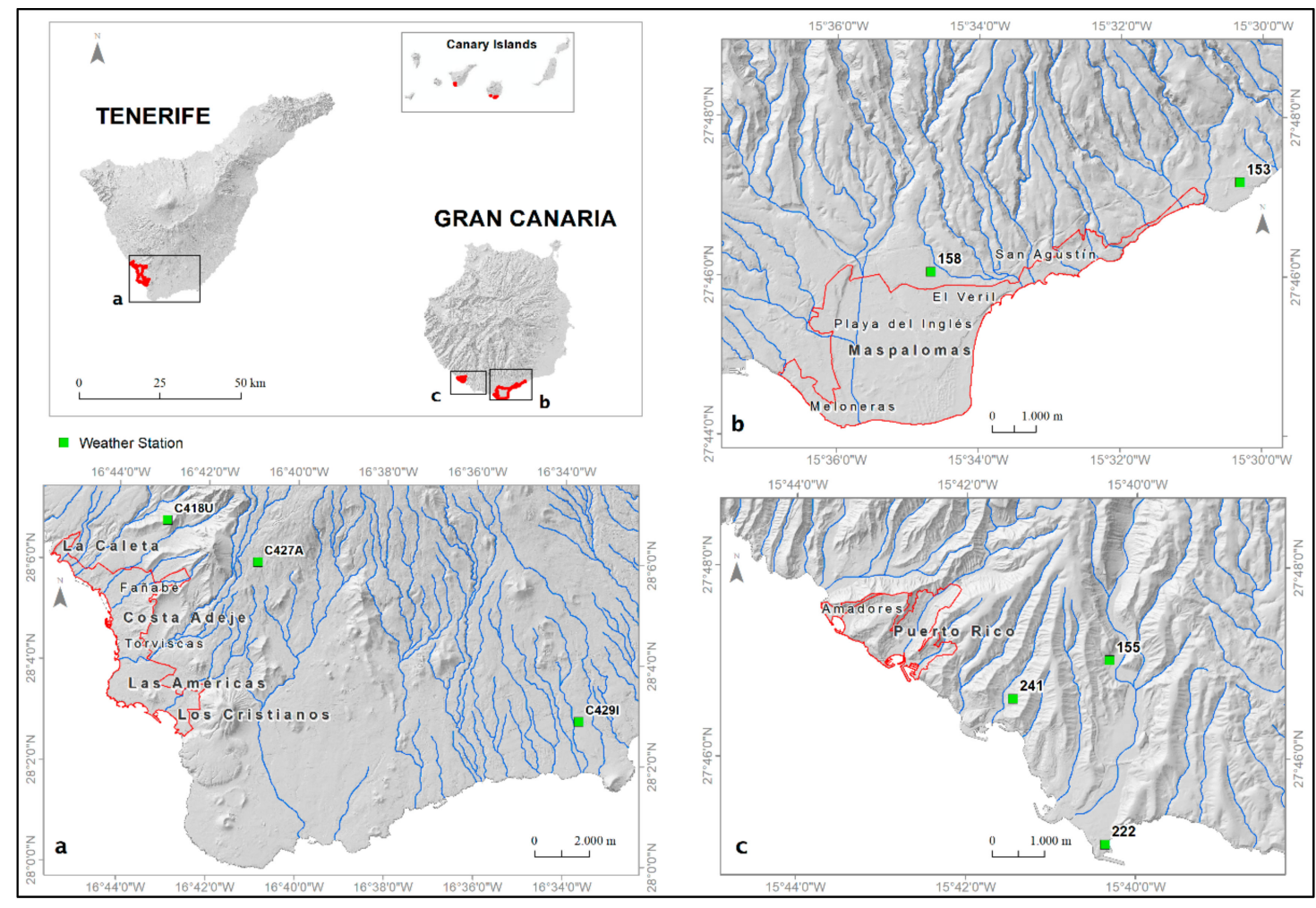

Figure 1. Location of the study areas in the islands of Tenerife and Gran Canaria, and location of the weather stations employed. (a) South Tenerife; (b) South Gran Canaria; (c) Southwest Gran Canaria.

\section{Data and Methodology}

\subsection{Statistical Analysis of the General Characteristics of the Rainfall}

Two data series were used for statistical analysis of the general characteristics of the rainfall in the two study areas. The first series (i) was recorded with the rain gauge of a weather station belonging to the State Meteorological Agency (Spanish initials: AEMET) situated at Reina Sofía international airport (C429I-Tenerife Sur) at a height above sea level of $64 \mathrm{~m}$. Daily data were obtained for the period 1981-2018 and hourly data for the period between October 1997 and December 2018. The daily series had no data missing but the hourly series did have some records missing in some months in the 2000-2005 period. The second series (ii) is that of the El Berriel (153-Berriel) part of the rain gauge network of the Gran Canaria Island Water Board (Spanish initials: CIAGC). It is situated in the south of Gran Canaria island at a height of $15 \mathrm{~m}$ above sea level and has continuous uninterrupted records for the period 1951-2018.

Various homogeneity tests were applied to both series, as have also been performed by other authors for the Macaronesia region [22]. For this, the standard normal homogeneity test (SNHT) [23], the Pettitt test [24], the Buishand range test, and the Von Neumann ratio test [25] were used. The C429I-Tenerife Sur series passed all four tests, demonstrating its homogeneity, but the 153-Berriel series displayed a certain discontinuity in its first years. This was due to climate causes, with the first years of the decade of the 1950s being an exceptional period of abundant episodes of rainfall in the Canary precipitation context $[26,27]$. 


\subsection{Identification of Episodes of Extreme Precipitation (Meteorological Records)}

In addition to the two series described above, data from a further eight weather stations were used for the selection of intense rainfall episodes. Five of these are situated on the island of Gran Canaria and form part of the CIAGC rain gauge network, and three are on Tenerife island and form part of the AEMET network. The Gran Canaria series are continuous and have no records missing but the Tenerife series have a number of gaps in the record for various months. Despite this shortcoming, the sole aim with these series was to select the most intensive rainfall episodes in the two study areas. It should be noted that it was decided to discard use of the Adeje (C-418U) rain gauge series despite its being the closest to the study area, as it contained the lowest number of data (its use was discontinued in 2007) and there were several gaps in the record. It was decided instead to use data from the Arona rain gauge (C427A), despite its higher altitude $(670 \mathrm{~m})$. Table 1 shows the data series that were used, their location, the start and end points of the series, and the total number of complete years of data. The intense rainfall episodes were distinguished using the 99th percentile of the daily rainfall data of the eight aforementioned series.

Table 1. Location, altitude, and time period of the rainfall series used in Tenerife (Tfe) and Gran Canaria (Gc).

\begin{tabular}{cccccccc}
\hline Station & Island & $\begin{array}{c}\text { Latitude } \\
(\mathbf{N})\end{array}$ & $\begin{array}{c}\text { Longitude } \\
(\mathbf{W})\end{array}$ & $\begin{array}{c}\text { Altitude } \\
(\mathbf{m})\end{array}$ & Start & End & $\begin{array}{c}\text { Complete } \\
\text { Years }\end{array}$ \\
\hline C429I-Tenerife Sur & Tfe & $27^{\circ} 59^{\prime} 29^{\prime \prime}$ & $16^{\circ} 41^{\prime} 10^{\prime \prime}$ & 12 & $07 / 1980$ & 2018 & 37 \\
\hline C418U-Adeje & Tfe & $28^{\circ} 06^{\prime} 40^{\prime \prime}$ & $16^{\circ} 42^{\prime} 59^{\prime \prime}$ & 266 & $04 / 1944$ & $08 / 2007$ & 25 \\
\hline C427A-Arona & Tfe & $28^{\circ} 05^{\prime} 51^{\prime \prime}$ & $16^{\circ} 40^{\prime} 57^{\prime \prime}$ & 670 & $11 / 1971$ & 2018 & 30 \\
\hline 153-Berriel & Gc & $27^{\circ} 47^{\prime} 05^{\prime \prime}$ & $15^{\circ} 30^{\prime} 29^{\prime \prime}$ & 15 & $09 / 1951$ & 2018 & 67 \\
\hline $\begin{array}{c}\text { 155-San José de } \\
\text { Arguineguín }\end{array}$ & Gc & $27^{\circ} 47^{\prime} 02^{\prime \prime}$ & $15^{\circ} 40^{\prime} 19^{\prime \prime}$ & 49 & $09 / 1949$ & 2018 & 69 \\
\hline 158-Maspalomas & Gc & $27^{\circ} 46^{\prime} 01^{\prime \prime}$ & $15^{\circ} 34^{\prime} 41^{\prime \prime}$ & 68 & $09 / 1949$ & 2018 & 69 \\
\hline 222-Arguineguín & Gc & $27^{\circ} 45^{\prime} 07^{\prime \prime}$ & $15^{\circ} 40^{\prime} 23^{\prime \prime}$ & 31 & $09 / 1949$ & 2018 & 69 \\
\hline 241-La Verga & Gc & $27^{\circ} 46^{\prime} 37^{\prime \prime}$ & $15^{\circ} 41^{\prime} 28^{\prime \prime}$ & 44 & $09 / 1949$ & 2018 & 69 \\
\hline
\end{tabular}

\subsection{Classification of Circulation Weather Types during the Extreme Rainfall Episodes}

After pinpointing the extreme rainfall episodes in the meteorological records, a classification was made of the weather type using an objective classification scheme based on circulation indices, as initially developed for the British Isles by Jenkinson and Collison [28], and, subsequently, Jones et al. [29] with a view to automatically reproducing the subjective classification of Lamb [30].

This method has been applied to many regions and with many different objectives, especially in Europe where there are examples from the Iberian Peninsula [31-34], Sweden [35,36], Scandinavia [37], Estonia [38], and the southwestern region of Russia [39]. It has also been employed in other regions such as Chile [40]. The classification is based on the use of a set of indices associated with the direction and vorticity of geostrophic flow. The indices used are as follows: westerly flow (WF), southerly flow (SF), total flow (F), westerly shear vorticity (ZW), southerly shear vorticity (ZS), and total shear vorticity (Z). These indices were calculated using the sea level pressure values obtained from the database Daily Northern Hemisphere Sea Level Pressure Grids [41] for the 16 grid points shown in Figure 2. This grid corresponds to an area defined from $40^{\circ} \mathrm{N}$ to $20^{\circ} \mathrm{N}$ and from $25^{\circ} \mathrm{W}$ to $10^{\circ} \mathrm{W}$, with a resolution of $5^{\circ}$. The analytical expressions used for the Canary Islands are shown in Figure 2. 


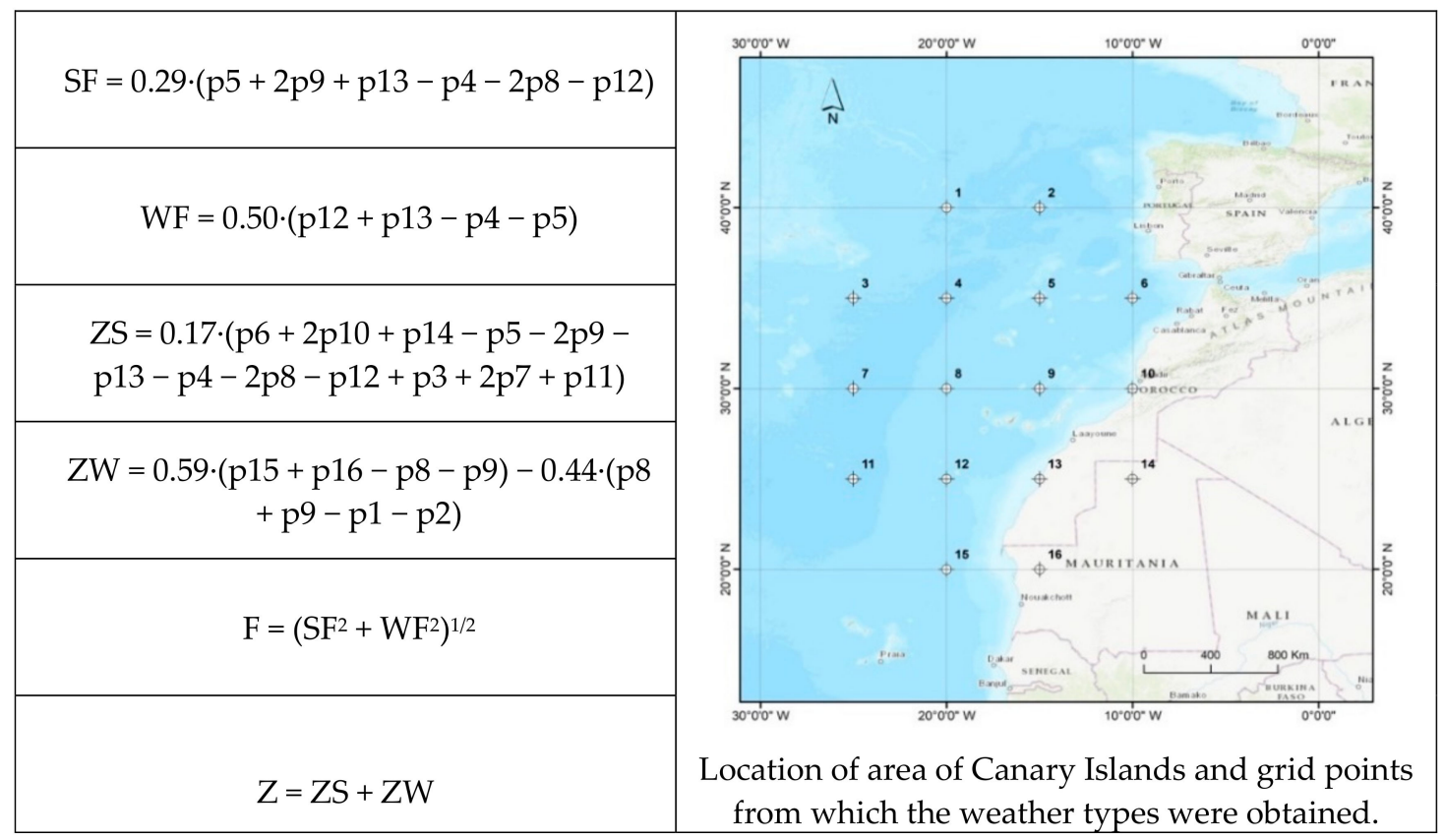

Figure 2. Equations for the calculation of circulation weather types according to Jenkinson and Collinson [28] and location of grid points centred around the Canary Archipelago for the calculation of flow (SF, WF) and vorticity (ZS, ZW). Legend: WF, westerly flow; SF, southerly flow; F, total flow; ZW, westerly shear vorticity; $Z S$, southerly shear vorticity; $Z$, total shear vorticity.

Definition of the type of circulation was determined in accordance with the following considerations:

1. Flow direction is obtained from $\tan ^{-1}$ (WF/WS), (an 8-point wind rose is used, and the sign of WF and WS is taken into account).

2. If $|Z|<F$ then flow is essentially a pure directional type, defined according to the following directions $(N$, $N E, E, S E, S S W, W$, and NW).

3. If $|Z|>2 F$ then flow is a pure cyclonic type (C) if $Z>0$, or anticyclonic ( $A$ ) if $Z<0$.

4. If $F<|Z|<2 F$ then flow is a hybrid type, depending on the sign of $Z$ (rule 3 ) and the flow direction (rule 1) (CN, CNE, CE, CSE, CS, CSW, CW, CNW, AN, ANE, AE, ASE, AS, ASW, AW, and ANW).

5. If both $F$ and $|Z|$ have a value below 6 , then flow type is defined as unclassified (U).

Thus, there are 27 weather types: anticyclonic (A), cyclonic (C), eight types according to geostrophic directional flow, another 16 hybrid (cyclonic or anticyclonic) types, and, finally, those which it was been possible to classify $(\mathrm{U})$.

\subsection{Determination of the Distribution Functions Which Best Fit the Rainfall Data Series}

The free software programme HYDROGNOMON (Version 4.1.0(.26)) was used to find the distribution function of extreme variables which best fits the two data series of daily rainfall. This is a programme that was specifically developed for the analysis and processing of hydrological series by the ITIA research group of the National Technical University of Athens [42]. Among the various applications in the software programme are the fitting of distribution functions and extreme variables, with multiple options including non-parametric (Weibull) and parametric methods (Normal, LogNormal, Pearson III, LogPearson III, Gumbel (EV1), GEV-Max, Pareto, Gamma, and Exponential). The programme also allows the application of parameter estimation methods, including the method of moments, the maximum likelihood method, and the linear moments or probability-weighted moments method (L-Moments). Thus, a total of 27 distribution functions were able to be applied to the different rainfall time series. To determine the best fitting function, the programme allows the Chi-squared and 
the Kolmogorov-Smirnov goodness-of-fit tests to be performed. After selection of this function, the probable maximum $24 \mathrm{~h}$ precipitation values for return periods of 25,50 and 100 years were calculated.

\subsection{Determination of the Socioeconomic and Territorial Consequences of Extreme Rainfall Episodes}

After identifying the days of extreme rainfall, the economic and territorial consequences for the various tourist developments affected were determined. This was achieved by consulting two documentary sources. The first of these was the database of the Insurance Compensation Consortium (Spanish initials: CCS) of Spain, who provided records of flood damage compensation payments for the period 1998-2016. It should be noted that this Consortium provides compensation payments for those affected by damage caused by natural phenomena or as the result of political or social events on the condition that the people or goods affected have insurance cover. Thus, the database provided contains the amount of each loss, distinguishing between shops and warehouses, dwellings and owners' associations, industrial goods, and vehicles. The Organic Law 3/2018, of December 5, on the Protection of Personal Data and the Guarantee of Digital Rights, prohibits the Consortium from supplying the names or postal addresses of affected entities or individuals, and so the database identifies each case by postcode, population centre, and municipality. By combining these three elements, each case can be assigned to an area whose size will essentially depend on the surface area covered by the particular postcode. The second type of documentary evidence was obtained by consulting all the newspapers that were published on the two islands on the day before and the days after the selected rainfall event. This was done with the aim of determining the precise locations of the floods, which are occasionally directly referred to in different news articles, and to obtain a general idea of the impact that the event generated in the press [43]. The following newspapers were consulted: El Día, Diario de Avisos, La Gaceta de Canarias, La Tribuna de Canarias, La Provincia, El Eco de Canarias, and Canarias 7. Some of these newspapers began publishing prior to the starting date of some of the rainfall data series (the end of the 1940s). However, as no tourist buildings or infrastructure (properly speaking) were constructed until the 1960s, there were no news articles on the impact of intense rainfall events on them published before that decade [44,45].

In this way, it was possible to relate days of intense rainfall identified through the historical rainfall data records with the consequences or damages incurred in the study areas, including the flooding of specific areas or streets and residential, tourist, or commercial buildings, the precise location of collapsed rainwater drainage systems, and the impact on beaches or bathing areas, etc.

\section{Results}

\subsection{General Characteristics of the Rainfall}

Rainfall characteristics in the Canary Islands derive from a combination of the general atmospheric circulation and local geographic conditions [46,47]. With regard to the first factor, the possibility of rainfall depends on the presence and behaviour of the anticyclone known as the Azores High. Only when it withdraws from the synoptic space of the Canary Islands is the occurrence of temperate zone disturbances, whose fronts can bring significant precipitations to the archipelago, possible. At the same time, the orientation and altitude of the terrain or relief on each island, together with their latitudinal position, result in significant differences in the number, severity, and spatial distribution of precipitation $[48,49]$.

In general lines, the orientation of the relief sets apart two contrasting climate regions on both Gran Canaria and Tenerife. The northern windward slopes are characterised by abundant clouds, high relative humidity, and a temperate character, whereas the southern leeward zones are dry, sunny, and warmer. Altitude also plays an important role, with the coastal regions relatively warm with little rainfall, the mid-altitude areas temperate and with more abundant rainfall which is more irregular in the south than the north, and the highest areas of the islands cold and with few and markedly irregular precipitations [48]. In the particular case of Tenerife, the stratovolcano of Teide (3715 m) along 
with the Cañadas edifice and the Pedro Gil ridge allow a clear differentiation between the northern (windward) and southwestern (leeward) slopes, with our study area found on the south-facing slope below $200 \mathrm{~m}$ and displaying features of considerable dryness and very scarce rainfall. These features are also apparent on the lower southern slopes of Gran Canaria, which explains the high similarity in the results of the statistical analysis of the two selected rainfall data series C429I-Tenerife Sur and 153-Berriel. Given this similarity, it was decided to only show the results of the C429I-Tenerife/Sur weather station as this forms part of the AEMET network, an extremely reliable data source and the only one that can be analysed on the basis of hourly data records.

As mentioned above, the absence of rain is one of the main meteorological characteristics of these sectors, and, at the same time, is one of the main reasons why these sectors are particularly ideal for the development of the so-called 'sun and beach' type of tourism. This can be seen in the fact that of the 13,878 days of records from the C429I-Tenerife Sur station (1981-2018) rainfall only occurred on 879 days (barely $6 \%$ of the total number of days). The annual mean precipitation of $123.6 \mathrm{~mm}$ fell on an average of just 23 days a year. Interestingly, in the south of Tenerife, the annual percentage of more than 31 days without rainfall is $71 \%$, a value similar to that of the easternmost islands of the archipelago [48] and that of the southern sector of Gran Canaria (the records of the El Berriel station show dry sequences lasting more than a month, amounting to a percentage as high as $76 \%$ ). The longest sequence of consecutive dry days with no rain in the south of Tenerife was 215 days (from 20 March 1987 to 21 October 1987), and almost a whole year in the case of the south of Gran Canaria (348 days from 20 April 2011 to 1 April 2012). An analysis of the percentage of dry episodes according to their duration shows that $80 \%$ are sequences which last less than a month, $11 \%$ last two months, and $3 \%$ three months and six months (Figure 3a). By contrast, the analysis of rainy spells shows a high probability of rain falling on just one day (60\%), while two-day-long episodes correspond to $20 \%$ and rainy periods of 6 days or longer only $2 \%$ (Figure 3b). As pointed out by Máyer and Marzol [50], the frequency of one-day-long rainy spells is notably higher in the easternmost islands of the archipelago and in the coastal and low altitude sectors of the other islands. Moreover, the amount of water accumulated in these one-day periods—as a percentage of the total amount of rainfall—is also highly significant, with this being a value of $23 \%$ in the case of Reina Sofía airport (a value similar to sites in the south of the easternmost islands of the archipelago).
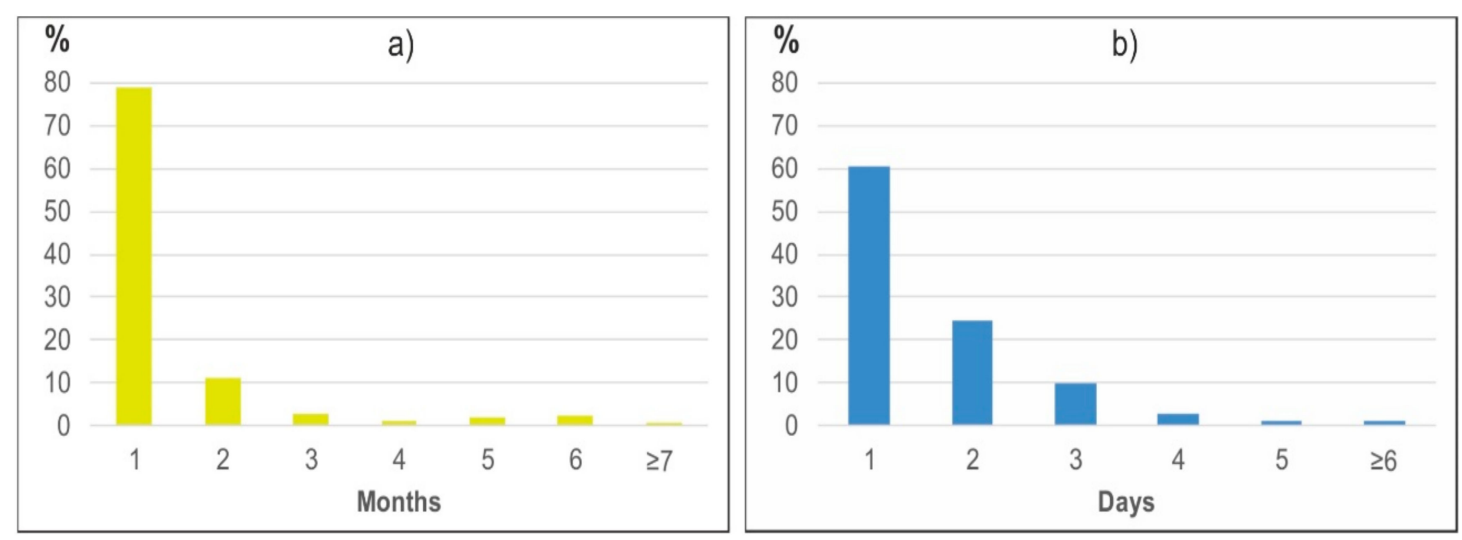

Figure 3. Frequency of the duration of dry spells (a) and rainfall episodes (b). Source: State Meteorological Agency (Spanish initials: AEMET).

With respect to the interannual variability of rainfall, it should be noted that a $90 \%$ confidence level in the mean value of the series would require an amplitude of 106 years, which would extend to 150 years for a $95 \%$ confidence level. In addition, the coefficient of variation displays exceptionally high values of $63 \%$ (Table 2), while the consecutive disparity index [51] is 0.72 . Both values are higher than those obtained for sites of greater rainfall irregularity in the Iberia peninsula [52]. As can be seen 
in Figure 4, it is normal that a dry year (1982) is followed by a rainy or very rainy (1983) year, or that a dry period is followed by a rainy one.

Table 2. Characteristics of monthly and annual precipitation in Reina Sofía airport in the south of Tenerife (1981-2018). Source: AEMET.

\begin{tabular}{|c|c|c|c|c|c|c|c|c|c|c|}
\hline Month & Mean & Median & $\mathrm{SD}^{1}$ & $\mathrm{CV}^{2}$ & $\begin{array}{l}\text { Monthly } \\
\text { Max }\end{array}$ & Year & $\begin{array}{l}\text { Daily } \\
\text { Max }\end{array}$ & Year & $\begin{array}{c}\text { Freq. } \\
\text { Days/Year }^{3}\end{array}$ & $\begin{array}{l}\text { Max. Freq. } \\
\text { Days/Year }\end{array}$ \\
\hline Jan & 14.9 & 2.3 & 25.9 & 174.2 & 135.2 & 2006 & 46.2 & 2007 & 11.3 & 13.2 \\
\hline Feb & 19.0 & 9.4 & 26.5 & 139.5 & 115 & 2005 & 61.0 & 1996 & 15.0 & 18.4 \\
\hline Mar & 12.7 & 3.8 & 21.8 & 171.7 & 101.2 & 1993 & 53.2 & 1993 & 10.6 & 10.5 \\
\hline Apr & 7.2 & 1.85 & 10.2 & 142.4 & 35.6 & 1997 & 20.4 & 1982 & 8.6 & 5.3 \\
\hline May & 0.9 & 0 & 2.0 & 226.9 & 8.4 & 2004 & 6.8 & 2006 & 2.7 & 0.0 \\
\hline Jun & 0.1 & 0 & 0.3 & 416.0 & 1.9 & 1993 & 1.0 & 1993 & 0.7 & 0.0 \\
\hline Jul & 0.0 & 0 & 0.2 & 616.4 & 1.5 & 1983 & 1.5 & 1982 & 0.1 & 0.0 \\
\hline Aug & 1.2 & 0 & 5.2 & 428.8 & 31 & 2005 & 18.5 & 2005 & 1.3 & 0.0 \\
\hline Sep & 3.0 & 0.2 & 5.2 & 173.2 & 19.2 & 1990 & 13.7 & 1990 & 5.0 & 0.0 \\
\hline Oct & 13.3 & 6.4 & 17.9 & 134.6 & 65.4 & 2006 & 47.0 & 1989 & 13.0 & 10.5 \\
\hline Nov & 22.5 & 6.3 & 40.7 & 180.4 & 212.8 & 1983 & 136.0 & 1983 & 13.2 & 21.1 \\
\hline Dec & 28.8 & 11.5 & 40.8 & 141.6 & 176.7 & 2013 & 109.0 & 2013 & 18.5 & 21.1 \\
\hline Year & 123.6 & 101.1 & 78.3 & 63.3 & 348.2 & 2006 & & & 100.0 & 100.0 \\
\hline
\end{tabular}

${ }^{1}$ Standard deviation. ${ }^{2}$ Coefficient of variation. ${ }^{3}$ Percentage of rainy days. ${ }^{4}$ Maximum precipitation value in a $24 \mathrm{~h}$ period. Source: AEMET.

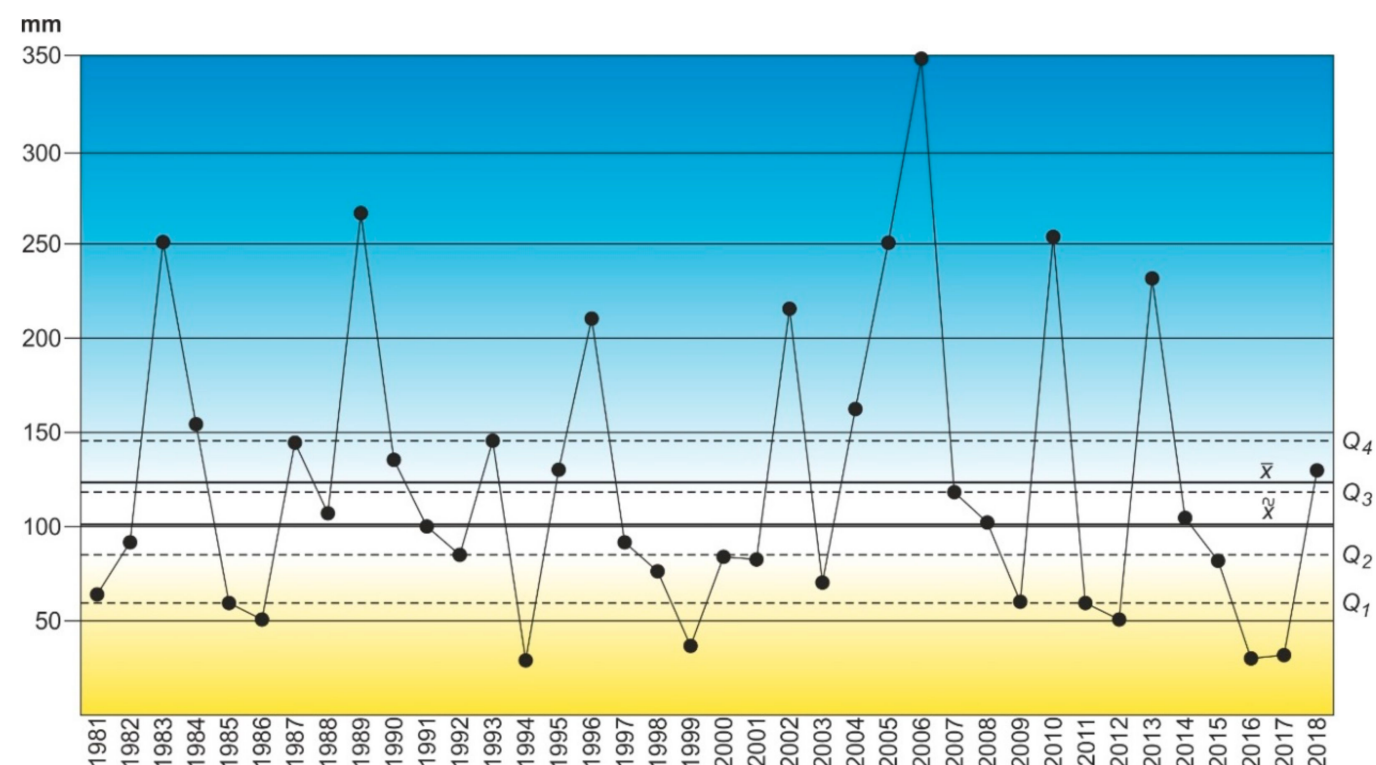

Figure 4. Total annual precipitation in Reina Sofía airport in the south of Tenerife (1981-2018). $Q_{1}$, $\mathrm{Q}_{2}, \mathrm{Q}_{3}$ and $\mathrm{Q}_{4}$ are the values of the percentiles which divide these series into 5 equal parts and allow differentiation between very dry years $\left(\leq Q_{1}\right)$, dry years $\left(>Q_{1}\right.$ and $\left.\leq Q_{2}\right)$, normal years $\left(>Q_{2}\right.$ and $\leq$ $\left.\mathrm{Q}_{3}\right)$, rainy years $\left(>\mathrm{Q}_{3}\right.$ and $\left.\leq \mathrm{Q}_{4}\right)$ and very rainy years $\left(>\mathrm{Q}_{4}\right)$. Source: AEMET.

December, which is one of the months with the highest number of tourist visitors to the island, is usually the rainiest month in the south-facing coastal areas and generally has the highest number of days of rainfall and the rainiest day of the year [53] (Table 2). Another distinguishing feature of the rainfall is its torrential nature. Considering only the 6 months in which $96 \%$ of the rainfall is concentrated (October to April), on occasions the mean value is exceeded by as high as a factor of 9 . This is the case of January of 2006 (135.2 mm versus a mean value of $14.9 \mathrm{~mm}$ ), November of 1983 (212.8 $\mathrm{mm}$ versus a mean of $22.5 \mathrm{~mm}$ ), and December of 2013 (176.7 mm versus a mean value of $28.8 \mathrm{~mm}$ ).

The amount of water that fell on the rainiest day of each year was usually more than $15 \%$ of each year's total rainfall. In fact, in 25 of the 38 years of the series $(66 \%)$, the rainiest day saw the accumulation of between $20 \%$ and $40 \%$ of the year's total rainfall. Extreme examples can be found 
in 1983 and 1994, when the maximum rainfall in one $24 \mathrm{~h}$ period corresponded to almost $50 \%$ of all the rainfall accumulated over the whole year. If the analysis is made for monthly totals, the daily maximum is generally more than $60 \%$ of the month's total rainfall. In 7 years of the series (almost $20 \%$ ), the rain that fell on the rainiest day of the year corresponded to more than $80 \%$ of all the rainfall for the corresponding month. All of the above examples show the importance of cloudbursts that are associated with the fronts of disturbances that affect this area of the island and which considerably increase the annual and monthly rainfall totals.

The analysis of the intensity of daily rainfall showed it to be weak or very weak, as $85 \%$ of the days with rain generally had values of between 0.1 and $9.9 \mathrm{~mm}$. However, the significant value of the daily precipitation concentration index [54], 0.69 , indicates that $25 \%$ of the rainiest days contributed to more than $80 \%$ of the rainfall. It should also be noted that the maximum amount of rain recorded on a single day was $136.0 \mathrm{~mm}(19 / 11 / 1983)$.

Hourly precipitation data for Reina Sofía airport were available for analysis for the period from 28 September 1997 to 31 December 2018. However, there are various gaps in the records; there are days when rain fell but for which no hourly records are available (474 days when the hourly record was complete and 48 when there were technical problems and no hourly records were kept). These technical problems affected days of some months in the 2000-2005 period. Despite this drawback, it is interesting to see the hourly precipitation behaviour with a view to establishing a relationship between the duration of the precipitation and the reference data of floods in the study area, as well as for a detailed analysis of the most significant rainfall episodes.

In this respect, it can be deduced from the hourly precipitation analysis that the most common precipitation event is of a single hour's duration (35\%), followed by 2 and $3 \mathrm{~h}(21 \%$ and $12 \%$, respectively). That is, as can be seen in Figure 5, when it rains in the south of Tenerife, it tends to do so with a duration of between 1 and $3 \mathrm{~h}(69 \%)$.

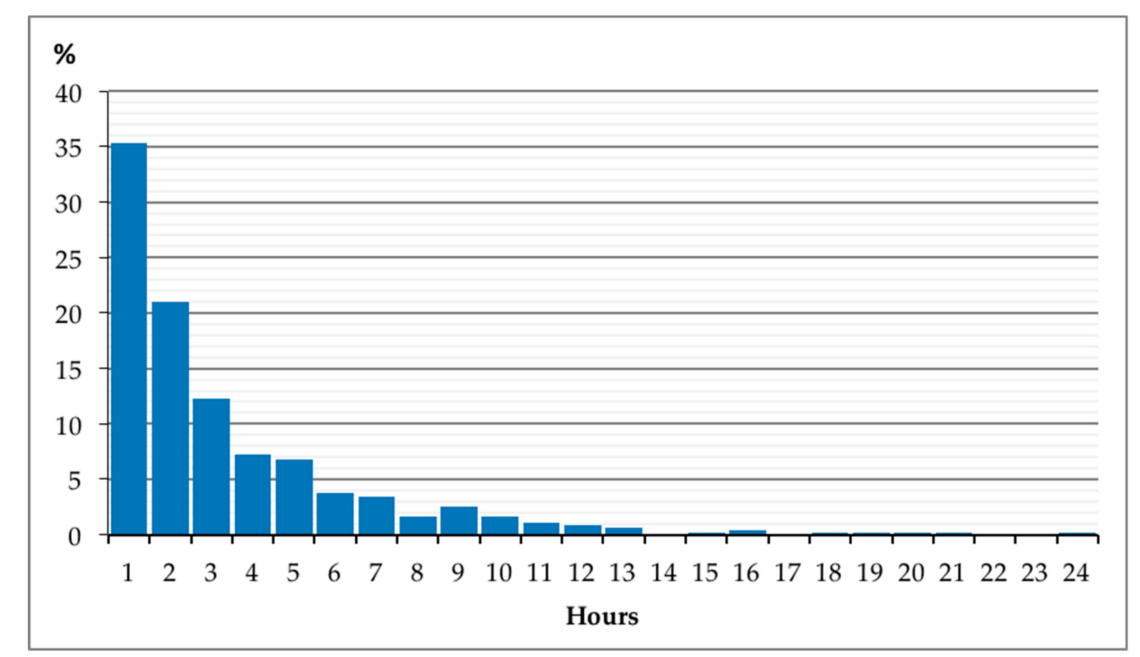

Figure 5. Hourly rainfall frequency in Reina Sofía airport in the south of Tenerife (1997-2018). Source: AEMET.

\subsection{Identification of Extreme Rainfall Episodes and Associated Weather Types}

As indicated in the methodology, the selection of intense rainfall episodes was made using the 99th percentile of the daily data of the eight selected series. These values are given in Table 3.

A total of 49 days corresponding to 41 rainfall episodes were selected. As can be seen in Table 4, the month with the highest number of days on which the 99th percentile was exceeded is November (17 days), followed by December (11 days), February (8 days), March and October (4 days), January (3 days), April and August (1 day). Most of the selected episodes were in winter (45\%), followed by autumn $(43 \%)$, spring $(10 \%)$, and summer $(2 \%)$. 
Table 3. Values of the 99th percentile in the different series used.

\begin{tabular}{cccc}
\hline Series & Percentile 99 & Series & Percentile 99 \\
\hline C429I-Tenerife-Sur & 47.1 & 155-San José de Arguineguín & 58.7 \\
C418U-Adeje & 78.8 & 158-Maspalomas & 50.0 \\
C427A-Arona & 65.1 & 222-Arguineguín & 50.7 \\
153-Berriel & 58.2 & 241-La Verga & 56.6 \\
\hline
\end{tabular}

Sources: AEMET and Gran Canaria Island Water Board (Spanish initials: CIAGC).

Table 4. Selection of days of rain according to the daily data series considered in this study and weather types (J\&C) defined according to the classification of Jenkinson and Collison (1977). The records selected according to the 99th percentile of their respective series are shown in bold.

\begin{tabular}{|c|c|c|c|c|c|c|c|c|c|c|}
\hline \multirow{2}{*}{ No. } & \multirow{2}{*}{ Date } & \multicolumn{3}{|c|}{ Tenerife } & \multicolumn{6}{|c|}{ Gran Canaria } \\
\hline & & C429I & C418U & C427A & 153 & 155 & 158 & 222 & 241 & $\mathrm{~J} \& \mathrm{C}$ \\
\hline 1 & $28 / 11 / 1949$ & N/A & 89.0 & N/A & N/A & 1.8 & N/A & 1.2 & 1.3 & $\mathrm{~S}$ \\
\hline 2 & $10 / 11 / 1950$ & N/A & N/A & N/A & N/A & 60.3 & N/A & 79.6 & 92.6 & $\mathrm{U}$ \\
\hline 3 & $21 / 01 / 1953$ & N/A & 80.0 & N/A & 0.0 & 0.0 & 0.0 & 2.3 & 2.6 & CNE \\
\hline 4 & $10 / 12 / 1953$ & N/A & N/A & N/A & 36.8 & 16.5 & 66.5 & 15.1 & 17.6 & C \\
\hline 5 & $22 / 11 / 1954$ & N/A & 11.3 & N/A & 13.4 & 17.6 & 37.9 & 82.0 & 95.3 & $\mathrm{U}$ \\
\hline 6 & $23 / 11 / 1954$ & N/A & 0.0 & N/A & 76 & 64 & 79.8 & 2.0 & 2.3 & $\mathrm{NE}$ \\
\hline 7 & 24/11/1954 & N/A & 0.0 & N/A & 53.3 & 3.8 & 60.6 & 43.4 & 50.5 & $\mathrm{~N}$ \\
\hline 8 & 25/11/1954 & N/A & 0.0 & N/A & 70.4 & 53.4 & 35.6 & 0.0 & 0.0 & $\mathrm{~N}$ \\
\hline 9 & $23 / 10 / 1955$ & N/A & N/A & N/A & 60.5 & 14.5 & 9.5 & 104.0 & 120.9 & $\mathrm{NE}$ \\
\hline 10 & 24/10/1955 & N/A & N/A & N/A & 0.0 & 119.1 & 116.5 & 14.5 & 16.8 & $\mathrm{~N}$ \\
\hline 11 & $28 / 11 / 1957$ & N/A & N/A & N/A & 58.0 & 0.0 & 50.3 & 0.0 & 0.0 & $\mathrm{U}$ \\
\hline 12 & $22 / 11 / 1967$ & N/A & N/A & N/A & 58.2 & 58.6 & 29 & 46 & 56.7 & C \\
\hline 13 & $24 / 11 / 1968$ & N/A & 17.1 & N/A & 26.4 & 61.2 & 27 & 48 & 60.0 & $\mathrm{CE}$ \\
\hline 14 & $31 / 12 / 1968$ & N/A & 83.0 & N/A & 42.8 & 25.0 & 40.3 & 13.8 & 11.3 & C \\
\hline 15 & $10 / 02 / 1971$ & N/A & 8.3 & N/A & 14.3 & 17.5 & 50.3 & 18 & 20 & $\mathrm{U}$ \\
\hline 16 & $11 / 02 / 1971$ & N/A & 3.8 & N/A & 76.0 & 32.8 & 40.4 & 19 & 25.8 & $\mathrm{NE}$ \\
\hline 17 & $12 / 02 / 1971$ & N/A & 0.0 & N/A & 57.0 & 80 & 49.5 & 36 & 27.3 & C \\
\hline 18 & 17/12/1972 & N/A & 0.0 & N/A & 60.3 & 48 & 67.5 & 36 & 33.1 & $\mathrm{~N}$ \\
\hline 19 & $10 / 04 / 1977$ & N/A & N/A & 95.0 & 3.2 & 0.0 & 0.0 & 0.0 & 0.0 & $\mathrm{~S}$ \\
\hline 20 & 19/11/1983 & 136.0 & N/A & N/A & 1.6 & 1.0 & 0.0 & 1.0 & 3.4 & $\mathrm{NE}$ \\
\hline 21 & 09/12/1984 & 7.7 & N/A & N/A & 126.0 & 41.8 & 66.6 & 60.0 & 51.0 & $\mathrm{C}$ \\
\hline 22 & $16 / 02 / 1989$ & 2.3 & 5.4 & 16.3 & 54.3 & 36.0 & 46.4 & 47.0 & 58.6 & CSE \\
\hline 23 & $24 / 11 / 1989$ & 96.5 & 100.2 & 91.0 & 25.5 & 44.0 & 47.7 & 33.0 & 32.0 & $\mathrm{CNE}$ \\
\hline 24 & $17 / 03 / 1993$ & 53.2 & 47.6 & 63.5 & 1.8 & 2.1 & 1.0 & 2.5 & 0.0 & $\mathrm{CE}$ \\
\hline 25 & 28/10/1993 & 9.8 & 78.8 & 62.0 & 25.2 & 13.7 & 11.5 & 20.0 & 5.3 & CSE \\
\hline 26 & $14 / 03 / 1995$ & 3.0 & 0.6 & 2.0 & 14.0 & 8.8 & 10.0 & 53.0 & 4.2 & $\mathrm{C}$ \\
\hline 27 & 13/12/1995 & 31.9 & 72.3 & 67.0 & 0.8 & 0.0 & 0.0 & 0.0 & 0.0 & C \\
\hline 28 & $02 / 02 / 1996$ & 61.0 & 27.0 & 22.0 & 39.5 & 24.2 & 44.0 & 36. & 20.2 & $\mathrm{U}$ \\
\hline 29 & 04/03/1996 & 29.6 & N/A & 72.0 & 18.2 & 13.0 & 17.0 & 16.4 & 14.0 & C \\
\hline 30 & $07 / 01 / 2000$ & 2.8 & 0.9 & 17.6 & 0.0 & 38.3 & 63.0 & 53.0 & 45.5 & CSE \\
\hline 31 & $11 / 11 / 2000$ & 14.0 & 44.0 & 74.0 & 0.0 & 0.0 & 0.0 & 0.0 & 0.0 & $\mathrm{U}$ \\
\hline 32 & 19/11/2001 & 13.5 & 31.0 & 39.6 & 62.0 & 59.9 & 50.0 & 41.0 & 102.0 & C \\
\hline 33 & $20 / 11 / 2001$ & 0.9 & 0.0 & 10.0 & 85.0 & 60.3 & 90.5 & 68.0 & 28.0 & $\mathrm{~N}$ \\
\hline 34 & $12 / 12 / 2002$ & 39.5 & 71.0 & 76.0 & 8.2 & 21.7 & 9.0 & 8.0 & 23.0 & C \\
\hline 35 & $16 / 12 / 2002$ & 42.1 & 82.0 & 97.6 & 20.1 & 18.1 & 17.5 & 9.0 & 77.0 & $\mathrm{NE}$ \\
\hline 36 & $17 / 12 / 2002$ & 4.8 & 10.0 & 2.1 & 86.3 & 69.8 & 73.5 & 47.0 & 16.5 & $\mathrm{~N}$ \\
\hline 37 & $19 / 02 / 2004$ & 30.3 & 63.0 & 94.7 & 25.3 & 17.4 & 21.5 & 15.0 & 14.0 & C \\
\hline 38 & $24 / 02 / 2005$ & 56.8 & 20.0 & 36.1 & 10.5 & 11.1 & 16.0 & 7.0 & 9.2 & C \\
\hline 39 & $02 / 03 / 2005$ & 17.5 & N/A & 81.0 & 8.5 & 13.7 & 9.0 & 11.0 & 13.8 & C \\
\hline 40 & 18/08/2005 & 18.5 & 81.0 & 57.2 & 1.3 & 3.0 & 0.6 & 2.0 & 2.9 & $\mathrm{~N}$ \\
\hline 41 & $20 / 12 / 2005$ & 25.2 & 55.0 & 65.2 & 60.0 & 67.5 & 42.0 & 59.0 & 66.9 & C \\
\hline 42 & $23 / 01 / 2006$ & 26.1 & 2.4 & 95.2 & 70.0 & 11.5 & 27.0 & 25.0 & 10.9 & U \\
\hline 43 & $28 / 10 / 2006$ & 46.1 & 4.8 & 48.6 & 33.0 & 44.2 & 11.0 & 36.0 & 85.5 & $\mathrm{CNE}$ \\
\hline 44 & $01 / 11 / 2006$ & 81.2 & 14.5 & 28.0 & 6.2 & 2.9 & 2.3 & 0.0 & 2.7 & CNE \\
\hline 45 & 29/11/2010 & 47.5 & N/A & 54.0 & 73.3 & 73.3 & 75.0 & 74.0 & 47.4 & $\mathrm{CN}$ \\
\hline 46 & 02/12/2013 & 32.1 & N/A & 83.0 & 3.5 & 10.5 & 15.0 & 1.8 & 10.2 & CSE \\
\hline 47 & 11/12/2013 & 109.0 & N/A & 158.0 & 29.6 & 13.2 & 12.0 & 12.1 & 12.2 & AN \\
\hline 48 & 19/11/2014 & 0.9 & N/A & 0.0 & 30.2 & 61.3 & 26.0 & 57.0 & 49.7 & CS \\
\hline 49 & $25 / 02 / 2018$ & 57.2 & N/A & 30.0 & 5.1 & 5.3 & 16.0 & 10.0 & 2.0 & CNE \\
\hline
\end{tabular}

Sources: AEMET and CIAGC. N/A = data not available. 
With respect to weather types, according to the analysis of the atmospheric status during the selected days of rain, those classified as pure directional type $(28 \%)$, cyclonic $(29 \%)$, and hybrid cyclonic ( $26 \%)$ were the most frequent, followed by unclassified (14\%); only one day ( $2 \%$ ) was classified as anticyclonic. However, if we consider days on which the thresholds considered were exceeded consecutively (five rainfall episodes), there is a clear prevalence of low-pressure fronts over the islands. Thus, the days 22-25 November of 1954 comprise a single advective-type event of the first quadrant (despite its being categorised on the first day as unclassified). The same is seen for 23-24 October of 1955 and 16-17 December of 2002. The 10-12 December episode of 1971 begins on the first with an unclassified categorisation and is followed by a pure directional type (NE), and on the final day (12 Dec) an area of low pressure settles over the archipelago. Finally, the 19-20 November episode of 2001 was classified as cyclonic on the first day and as a pure directional type $(\mathrm{N})$ on the second; in this case it is considered cyclonic. Table 5 shows the absolute and relative frequencies, considering both days and episodes as previously indicated.

Table 5. Absolute and relative frequencies of weather types of each of the days and episodes selected using the 99th percentile of the series considered.

\begin{tabular}{|c|c|c|c|c|c|}
\hline \multirow{2}{*}{\multicolumn{2}{|c|}{ Weather Type }} & \multicolumn{2}{|c|}{ Absolute Frequency } & \multicolumn{2}{|c|}{ Relative Frequency (\%) } \\
\hline & & \multirow{2}{*}{$\begin{array}{c}\text { Days } \\
14\end{array}$} & \multirow{2}{*}{$\begin{array}{c}\text { Episodes } \\
14\end{array}$} & \multirow{2}{*}{$\begin{array}{c}\text { Days } \\
29\end{array}$} & \multirow{2}{*}{$\begin{array}{c}\text { Episodes } \\
34\end{array}$} \\
\hline Cyclonic & C & & & & \\
\hline \multirow{3}{*}{$\begin{array}{l}\text { Directional } \\
\text { type }\end{array}$} & $\mathrm{N}$ & 7 & \multirow{3}{*}{8} & 14 & \multirow{3}{*}{20} \\
\hline & NE & 5 & & 10 & \\
\hline & $\mathrm{S}$ & 2 & & 4 & \\
\hline \multirow{5}{*}{$\begin{array}{l}\text { Hybrid } \\
\text { cyclonic }\end{array}$} & $\mathrm{CN}$ & 1 & \multirow{5}{*}{13} & 2 & \multirow{5}{*}{32} \\
\hline & $\mathrm{CNE}$ & 5 & & 10 & \\
\hline & CE & 2 & & 4 & \\
\hline & CS & 1 & & 2 & \\
\hline & CSE & 4 & & 8 & \\
\hline $\begin{array}{c}\text { Hybrid } \\
\text { anticyclonic }\end{array}$ & $\mathrm{AN}$ & 1 & 1 & 2 & 2 \\
\hline Unclassified & $\mathrm{U}$ & 7 & 5 & 14 & 12 \\
\hline Total & & 49 & 41 & 100 & 100 \\
\hline
\end{tabular}

Source: Daily atmospheric pressure data were obtained from the Daily Northern Hemisphere Sea Level Pressure Grids [41].

\subsection{Selection of the Distribution Function Which Best Fits the Rainfall Data}

As indicated in the methodology, with a view to determining the probability of extreme precipitation values for different return periods, it is of interest to know the distribution function which best fits the daily and hourly data of the series selected for statistical analysis. However, it should be noted that the low number of daily and hourly data of the C429I-Tenerife Sur series would make these results poorly representative. It was therefore decided not to apply these functions to the hourly data as they are only available for the periods 1998-1999 and 2016-2018 (only 17 years), whereas the 153-Berriel series contains 67 years of data.

Table 6 shows the three functions which gave the best results in both the Chi-squared and Kolmogorov Smirnov tests for the El Berriel series. Figure 6 shows, in turn, a visual analysis of the results obtained of the selected functions using the statistical criterion of goodness-of-fit. In this way, it was possible to select the function which best fits the data, and, therefore, preferentially consider it for the estimation of rainfall for diverse return periods. In this figure, it can be seen that the function which best fits the data of both series is the Log Pearson III. In addition, the results of maximum daily precipitation probability were obtained for each of the functions (Table 7). 
Table 6. Distribution functions which best fit the data records.

\begin{tabular}{cc}
\hline 153-El Berriel & C429I-Tenerife-Sur \\
\hline Chi-Squared Test & Chi-Squared Test \\
\hline 1. L-Moments GEV-Max (kappa specified) & Log Normal \\
2. Exponential & Log Pearson III \\
3. Log Pearson III & GEV-Max L-Moments \\
\hline Kolmogorov-Smirnov Test & Kolmogorov-Smirnov Test \\
\hline 1. GEV-Min L-Moments & Pareto L-Moments \\
2. Log Pearson III & GEV Min L-Moments \\
3. L-Moments GEV-Max (kappa specified) & Exponential \\
\hline
\end{tabular}

(a)
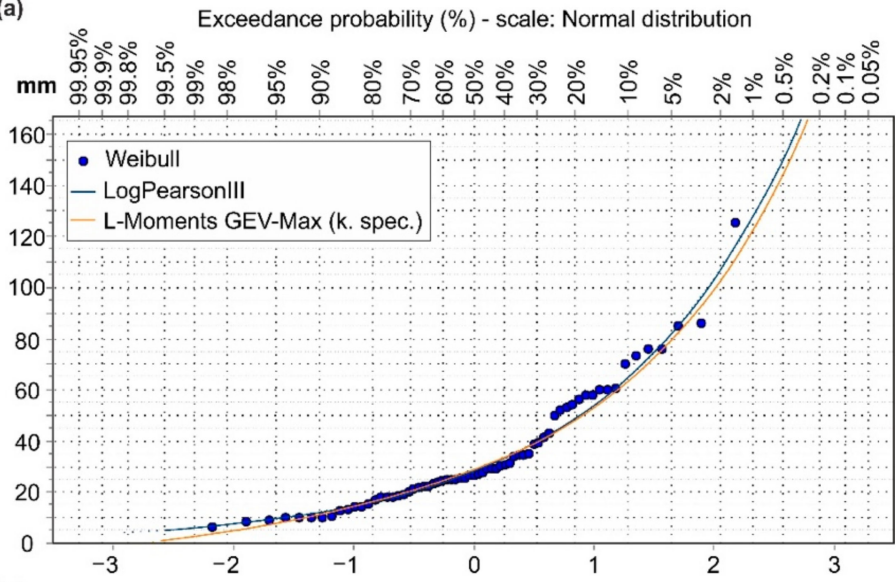

(b)

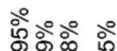

Exceedance probability (\%) - scale: Normal distribution

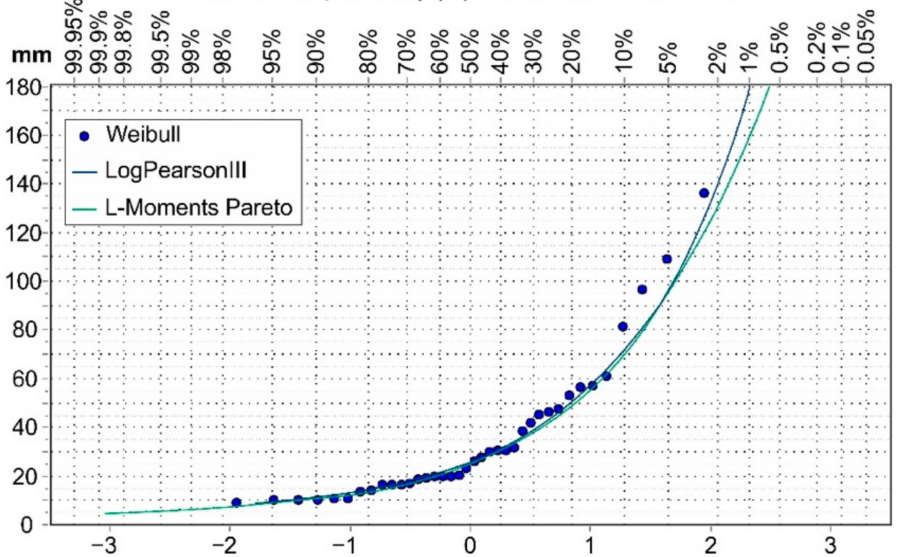

Figure 6. Graphical representation with the different functions which best fit the $24 \mathrm{~h}$ maximum precipitation values in the 153-Berriel (a) and C429I-Tenerife Sur (b) series. 
Table 7. Maximum daily precipitation probabilities according to the distribution functions.

\begin{tabular}{cccc}
\hline Function & $\mathbf{2 5}$ & $\mathbf{5 0}$ & $\mathbf{1 0 0}$ \\
\hline 153-El Berriel & & & \\
\hline Log Pearson III & 88.1 & 107.4 & 111.1 \\
L-Moments GEV-Max (kappa specified) & 84.5 & 102.7 & 122.6 \\
Exponential & 85.8 & 101.9 & 117.9 \\
L-Moments (GEV-Min) & 85.9 & 100.6 & 114.9 \\
\hline C429I-Tenerife-Sur & & & \\
Log Pearson III & 105.3 & 138.9 & 179.9 \\
L-Moments Pareto & 103.5 & 130.4 & 160.0 \\
L-Moments GEV-Max & 99.9 & 131.7 & 171.4 \\
L-Moments GEV-Min & 104.5 & 128.9 & 154.1 \\
Log Normal & 96.5 & 120.2 & 146.4 \\
\hline
\end{tabular}

\subsection{Determination of the Consequences of Extreme Precipitation Episodes}

There are 25 dates for which the 99th percentile of the Tenerife series was found to be equalled or exceeded, and 28 for the series of Gran Canaria. On only four days was the 99th percentile exceeded in one or more series of the two islands (Table 4), which demonstrates the very local character of torrential rains in the islands [49,55]. Only particular isolated situations of high-level depressions and low-pressure areas with highly active surface fronts which penetrate the islands through the $\mathrm{S}$ and SW are able to affect with a high degree of intensity all the slopes of the islands with the same orientations. On the other hand, as previously mentioned, the tourist development that has taken place in the study areas began in the 1960s and it is therefore unsurprising that there are no significant references in the press to flood damage in the areas under consideration before 1980. In the case of the island of Tenerife, the first news of flood damage in the study area was published on 19 November 1983 in relation to the $136.0 \mathrm{~mm}$ of rainfall that fell on Reina Sofía airport. Including that day and up until 2018, there are a total of 21 days when the 99th percentile of the Tenerife series was equalled or exceeded (Table 4). For all of these dates except five, news articles were published about problems caused by rainfall to tourist centres, as well as other nearby residential areas, in the south of Tenerife. With respect to Gran Canaria, the first journalistic record of weather-related damage to tourist infrastructure was the result of the rains of 9 December 1984-when $126.0 \mathrm{~mm}$ was recorded at El Berriel—with multiple references in the press to flood damage to hotels, apartments, and main roads in Maspalomas and Playa del Inglés. Including that day and up until 2018, there were a total of 13 days when the 99th percentile of the Gran Canaria series was equalled or exceeded (Table 4). In all cases except three, multiple incidents of damage were reported in the press to tourist establishments in San Agustín, Maspalomas, Playa del Inglés, Puerto Rico, and Amadores.

Flooding of Roads/Streets, Infrastructure, and Tourist Buildings

With respect to the consequences of these rains for the main roads which connect these tourist areas to other areas and important infrastructure like the airports on the islands, the most important are the disruptions to the circulation of traffic as the result of materials eroded by runoff water and transported from the slopes and inclines down onto the roads, as well as landslides and flooding caused by blockages of viaducts constructed over the ravines. In the case of Tenerife, such effects are repeatedly observed on the main route to the airport, the TF-1 motorway, as it passes by Costa Adeje. Problems are also frequently found on this motorway in the area close to Torviscas (Figure 7a). Photos and reports of flooding of the road that connects Los Cristianos with Playa de Las Américas are also repeatedly seen in the press, as well as other roads that are shown covered with stones, rocks, mud, and other materials swept down from the ravines and slopes. Equally serious consequences are commonly reported for the GC-500 dual carriageway, which serves as the communication axis for the various tourist resorts of San Agustín, Playa del Inglés, Maspalomas, Puerto Rico, and Amadores, as 
well as roads and streets in the resorts themselves which are flooded for the same reasons as explained above and become unpassable.

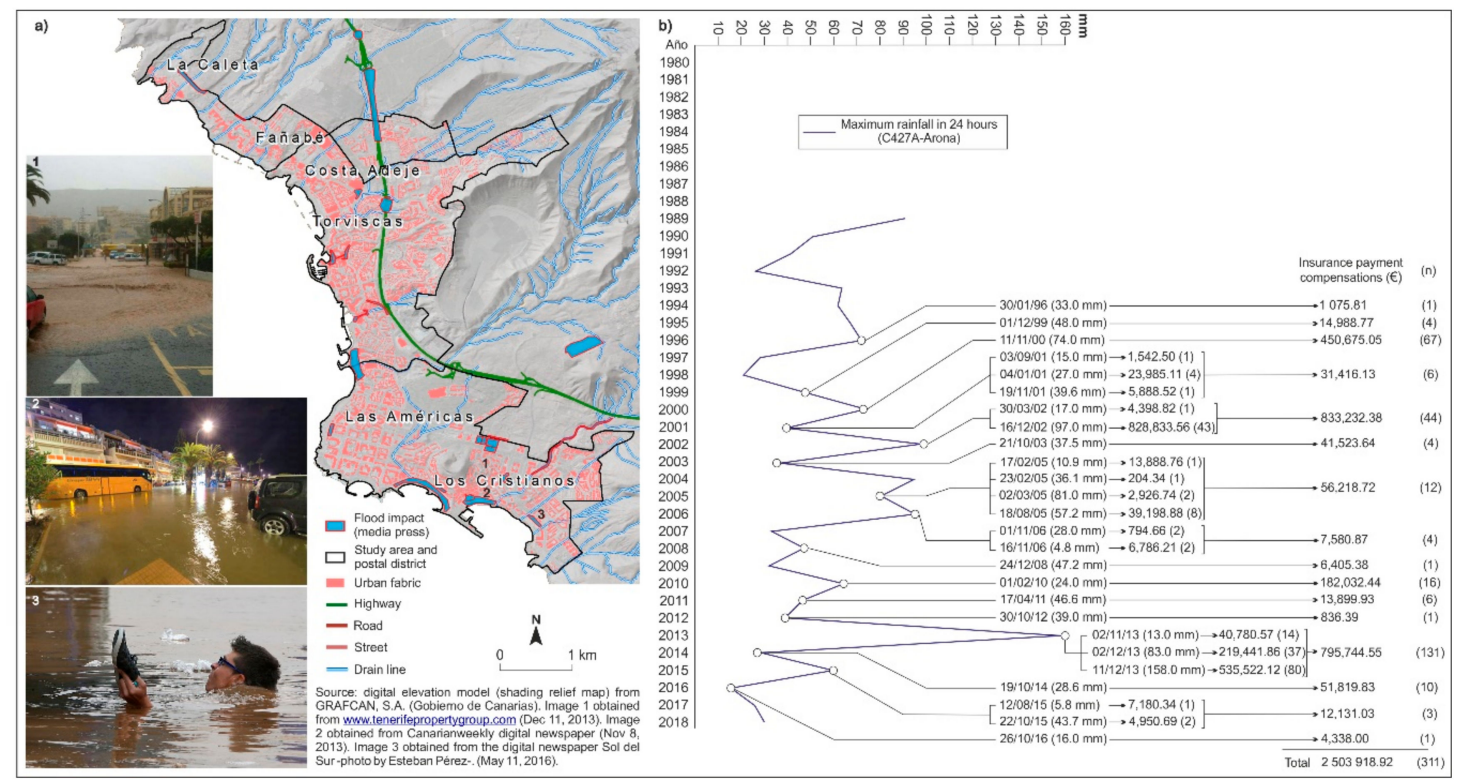

Figure 7. (a) Map showing the position of flooded areas in the tourist resorts of Playa de Las Américas and Los Cristianos situated in the municipalities of Arona and Adeje (Tenerife) between 1980 and 2018 and (b) compensations paid by the Insurance Compensation Consortium (Spanish initials: CCS) for the various losses that took place between 1996 and 2016.

With respect to the effects of these rainfalls on buildings and, in general, tourist establishments and shopping centres, the press, not always accurately, has reported flooding due to overflows of the natural courses of the ravines and of the flumes intended to carry away rainwater in the different ravines which cross the urban areas. In addition, it is common to find reports of the incapacity of the sewage network to transport the extra rainwater that enters the network. In these cases, the wastewater and rainwater break through the covers and drains situated in the ground floors of the buildings, causing flooding. Some hotels and apartments have one or more floors below street level but no pump system to remove the water and are flooded by the high levels of rainwater which flow down the streets and progressively accumulate in flatter areas.

As for the economic consequences associated with the floods in all the study areas that are considered in the present work, a total of $€ 12,416,806.86$ was paid out for 1032 incident claims based solely on data supplied by the CCS for the 1998-2016 period. In Tenerife (Figure 7b), a total of $€ 2.5$ million was paid out for 313 approved claims. The most expensive rainfall episode was that of 16-17 December of 2002 with $€ 0.8$ million paid out for 43 claims, while the second most serious was on 11 December 2013, with $€ 0.5$ million paid out for 80 claims. However, the areas with the highest compensation payments are in Gran Canaria, specifically in the tourist resorts of San Bartolomé de Tirajana (San Agustín, Playa del Inglés, and Maspalomas), where $€ 6.8$ million were paid out for a total of 495 approved insurance claims. The most severe economic consequences were the result of the 19-20 November rainfall episode of 2001, for which 302 insurance claims were approved for losses which amounted to $€ 4.5$ million. This was followed by the storm of 7 January 2000 which left losses of insured goods amounting to $€ 1.4$ million for 109 claims (Figure 8b). The municipality of Mogán and its tourist centres (Puerto Rico and Amadores) have seen more than $€ 3.1$ million paid out for 226 insurance claims. The worst rainfall episode for this municipality in terms of economic consequences was that of 20 December 2001, as a result of which more than $€ 1.8$ million was paid out for a total of 136 claims. This was followed by the 16-17 December episode of 2002, which resulted in compensation payments of $€ 1.1$ million for 53 claims (Figure 9b). 


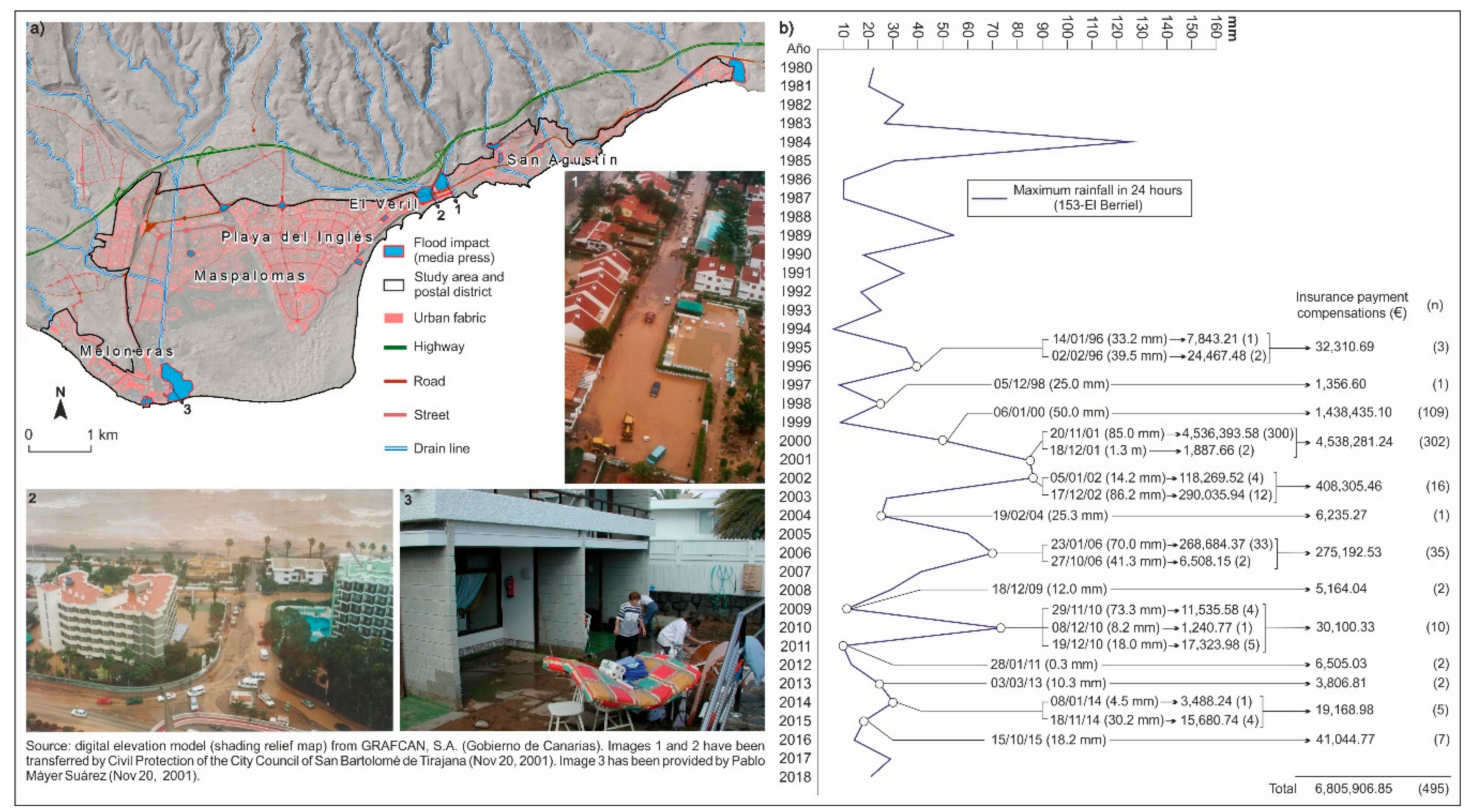

Figure 8. (a) Map showing the position of flooded areas in the tourist resorts of San Agustín, Playa del Inglés, and Maspalomas in the municipality of San Bartolomé de Tirajana (Gran Canaria) between 1980 and 2018 and (b) compensation payments made by the CCS for the different incidents that took place between 1996 and 2016 .
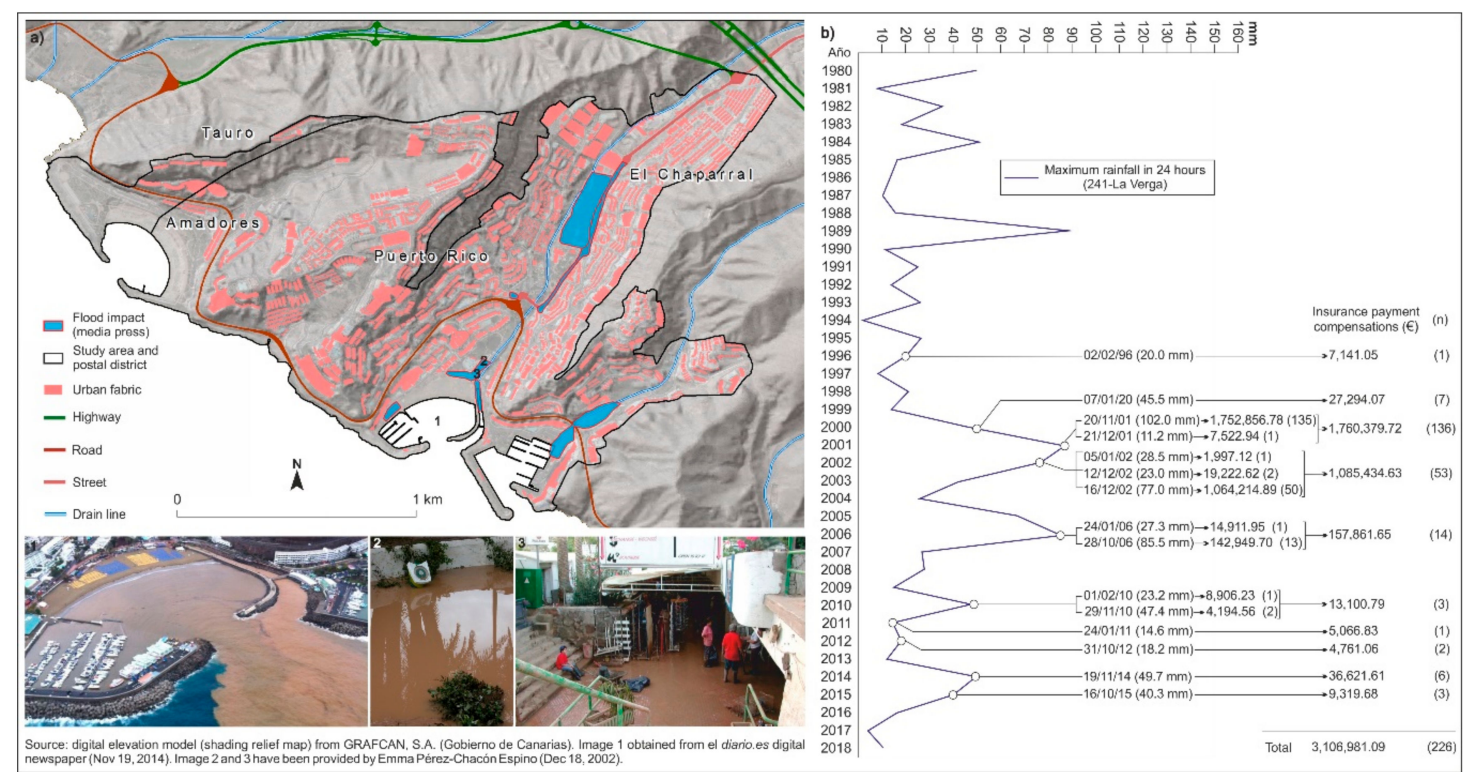

Figure 9. (a) Map showing the position of flooded areas in the tourist resorts of Puerto Rico and Amadores in the municipality of Mogán (Gran Canaria) between 1980 and 2018 and (b) compensation payments made by the CCS for the different losses that took place between 1996 and 2016.

Although these amounts may not seem overly excessive when speaking of a period of 18 years, it should be remembered that the CCS compensation payments are only an indicator to which have to be added the cost of other mechanisms used to re-establish interrupted economic activities, as well as the loss of income experienced by many indirectly affected businesses and services until the status quo is restored.

Importantly, the episodes of heavy damage occur with the same irregularity as the extreme rainfall episodes in the study area, with the result that very few events are responsible for significant amounts of damage. This is evidenced by the occurrence of three intense rainfall events at the beginning of the 
twenty-first century which had serious consequences for the tourist industry. These incidents acted as a wake-up call to the authorities about the seriousness of the potential material and physical damage due to the risk of flooding and the important damage to the image of the islands as a tourist destination. In the following years, various very expensive countermeasures were taken in an attempt to reduce the risk of flooding. These included widening of flumes and viaducts in the ravines, especially in Gran Canaria, and extension of the drainage system for rainwaters along several roads. Similarly, in the tourist centres of Tenerife, flumes were constructed in various ravines and berms were built to facilitate the transportation of runoff water from the slopes to these flumes. Major rainwater drainage networks were also built.

\section{Discussion}

In an archipelago which, as previously indicated, welcomed close to 16 million tourist visitors in 2018 and where the tourist sector is responsible for around a third of the islands' GDP, the damage caused by extreme rainfall events constitutes a major disruption to this economic activity and has a negative impact on the image of the islands' 'brand'.

The high degree of irregularity in these islands as far as rainfall is concerned means that, to date at least, flooding episodes tend to be restricted to certain especially vulnerable areas, are relatively infrequent, and produce moderate damage levels. However, relatively modest volumes of rainwater, as seen in the fact that the 99th percentile corresponds to only 50.0-80.0 mm of rain depending on the weather station (Table 3), can have important consequences which especially impact on tourist establishments and main roads and highways, particularly in Gran Canaria. In this respect, the three figures which relate rainfall events with CCS compensation payments show that claims for flood damage have been made when the amount of rainfall has been far less than that of the 99th percentile. This can be attributed to deficiencies in the rainwater drainage system in various tourist centres, to the extent that flood damage has been recorded in cases of rainfall of less than $20.0 \mathrm{~mm}$ in $24 \mathrm{~h}$. In this context, some studies have been made in the Canary Islands $[53,55,56]$ which show the consequences of the rapid and improperly planned urbanization process of various population centres, especially tourist ones. There are serious deficiencies in rainwater drainage systems, and the occupation of the natural courses of ravines and rights of way and the installation of flumes and weirs have been carried out with the intention of obtaining the maximum benefit possible from any available space [57]. Another factor has been the short-term expectations that have been generated in terms of immediate economic benefits (especially with respect to employment possibilities). Such a factor is very possibly the only explanation for the recent construction of a new system to reroute the watercourses of a natural floodplain (at a cost of more than $€ 2$ million) in order to facilitate the construction of a large leisure complex together with hotels and other services in El Veril (Figure 10). The probable construction of these new types of infrastructure and buildings in a high flood risk area is very difficult to justify if the geographic and rainfall characteristics of the area are taken into consideration.

The damage caused by rainfall in the Canary Islands only reveals one part of the problem. The maximum precipitations observed in the series that have been analysed, though very significant, were slightly less than $160 \mathrm{~mm}$. However, if the return periods found with the different distribution functions are considered, there is a strong possibility of considerably more severe rainfall events. On the basis of Log Pearson III, the distribution function which best fits the studied data series, there is a strong likelihood of far worse flood events than those that have occurred to date and, consequently, more extensive damage. According to the analysed data, the maximum rainfall recorded at the Tenerife Sur weather station was $136.0 \mathrm{~mm}$ in November 1983, while at the Berriel station the highest value was $126.0 \mathrm{~mm}$ in November 1984. Importantly, these events were 36 and 35 years ago, respectively, when the tourist industry in the islands was at a far earlier stage of development than it is today. However, for the south of Tenerife, if a return period of 100 years is considered, a maximum value of $180.0 \mathrm{~mm}$ is obtained. In other words, a volume of rain considerably higher than the maximum value recorded to date could fall in what is now an intensely urbanised space where over 80,000 tourists may be 
staying at a given moment. Such amounts are highly probable not only according to the function-based calculations but also in view of the fact that considerably higher volumes have already been recorded at other sites in the Canary Islands in similar geographic enclaves (on the eastern coasts). By way of an example, at El Hierro airport $287.0 \mathrm{~mm}$ of rain fell on 27 February 1988 and $232.00 \mathrm{~mm}$ in just $2.5 \mathrm{~h}$ between 16:00 and 18:30 on 31 March 2002 in Santa Cruz de Tenerife. Moreover, in the context of climate change and the reports of an increase in precipitation intensity [27,58], there is also a high probability of increased danger as the result of heavy rainfall.

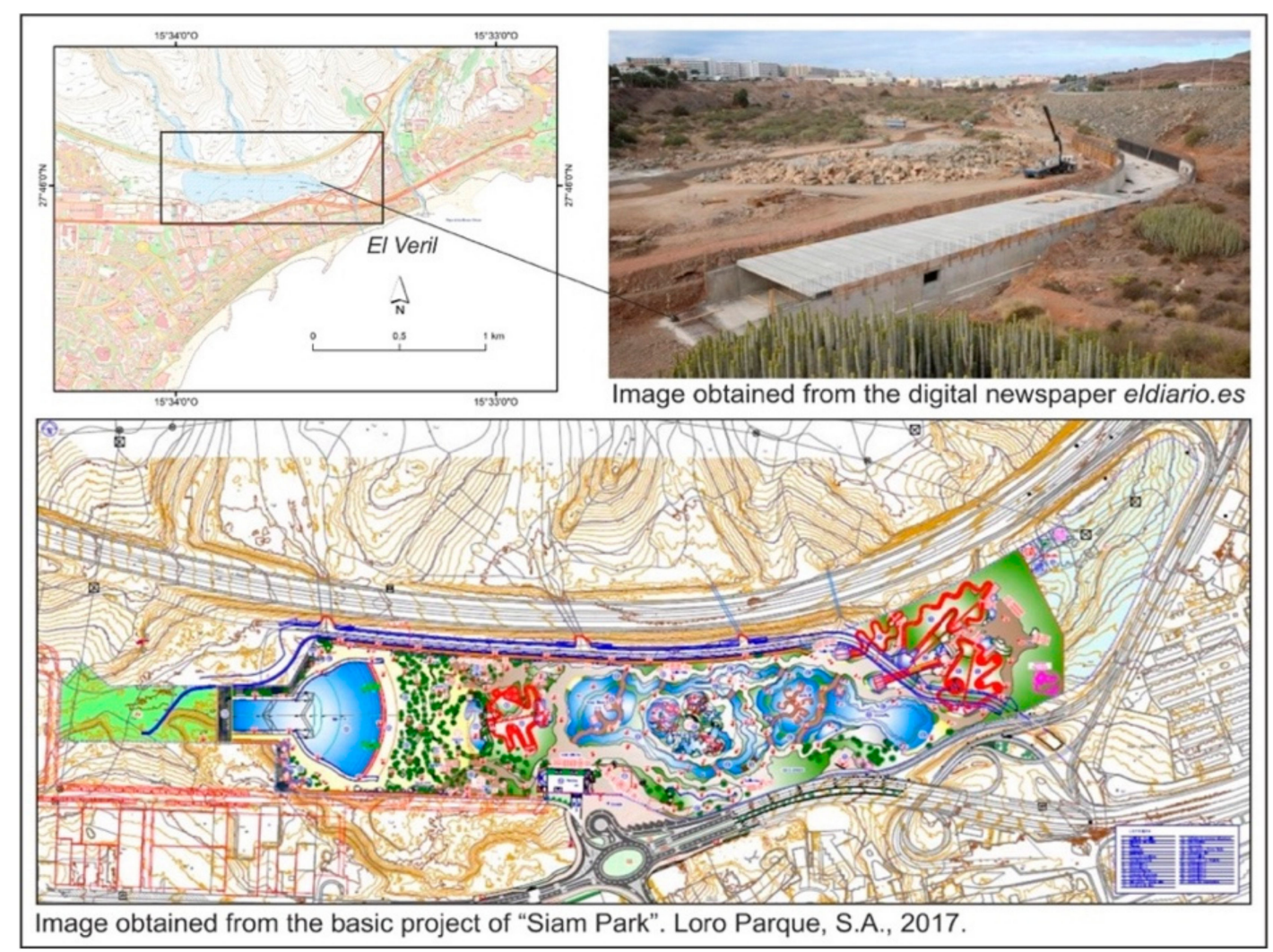

Figure 10. Location of El Veril ravine. Images are shown of the water rerouting system that has been carried out and the proposed construction of "Siam Park" in the natural floodplain and course of the ravine.

The intense rainfalls that resulted in flooding events display a strongly seasonal pattern, tending to coincide with the maximum rainfall period between the months of November and February (Table 4), although such events may also occur occasionally outside these months. Of the 41 episodes recorded, most were cyclonic and hybrid cyclonic weather type events, although the data show that they are intense and spatially very localized downpours. In other words, as is clear from the data (Table 4), the most extreme torrential episodes not only often do not affect the two islands considered in this study simultaneously, but they do not even affect all the catchment areas of an incline. There is clear evidence that in the Canary Archipelago, precipitations are highly concentrated in both time and space.

\section{Conclusions}

Our analysis of the consequences of intense rainfall episodes in the study areas confirms the observations of other authors on the Canary Islands, namely that, in terms of climate risks, these are the events which have caused the biggest economic losses in this territory.

Throughout its history, the archipelago has endured numerous meteorological events of this type, and the economic losses have been very high in recent decades. Most of these economic losses have affected tourist and urban spaces. In this respect, the problems that arise as a result of poor planning 
in terms of countering the possibility and impact of flooding in some tourist areas in the south of Gran Canaria are well known. This deficiency in territorial planning explains the effects of floods in areas of the islands exploited by the tourism industry. Nonetheless, it must be acknowledged that the highly irregular nature of rainfall in the islands does make adequate urban planning for each particular environment a difficult task.

The analysis that was conducted of the causes of the intense rains in terms of weather types found that those that resulted in the most highly concentrated rains in time and space were of the cyclonic type. At the same time, our analysis of press reports and insurance flood damage compensation payments enabled a very precise evaluation of the economic consequences of the intense rains and the exact location of the sites where the worst damages were reported. In addition, the analysis of return periods suggests that significantly more severe rainfall events than those recorded to date can be expected, and, hence, there is a strong likelihood of more extensive flooding damage in the future.

In view of the above, there is a need to augment the weather station network to have a far greater understanding of rainfall characteristics in spaces, like those of the study area, which are intensely developed and exploited for the purposes of tourism. It is equally important to adapt urban planning and the hydraulic infrastructure to take into account the extreme intense rainfall values that can be expected. In this context, one of the main cornerstones in the development of the tourist industry must be to meet the safety demands of holidaymakers, creating more sustainable spaces and reducing flood risks to the greatest extent possible. In addition, climate change could be a determining factor in the appearance of extreme rainfall events worse than those than those that have occurred to date and with the potential for very serious consequences for these sectors in the south of Tenerife and Gran Canaria.

Author Contributions: Conceptualization, A.L.D., P.M.S., J.D.P. and P.D.A.; Formal analysis, A.L.D., P.M.S., J.D.P. and P.D.A.; Methodology, A.L.D., P.M.S., J.D.P. and P.D.A.; Visualization, A.L.D. and P.D.A.; Writing-original draft, A.L.D., P.M.S. and P.D.A.; Writing-review \& editing, P.M.S. and J.D.P.

Funding: This research was funded by the Canary Government and the European Regional Development Fund (ERDF) to develop the research project "Flood impact analysis in coastal tourist areas: the Canary Islands-A natural laboratory of resilience" -ProId201710027-.

Conflicts of Interest: The authors declare no conflict of interest.

\section{References}

1. Vera Rebollo, F. Riesgos naturales en la actividad turística. Áreas. Revista de Ciencias Sociales 2003, 23, 159-176.

2. Gómez-Martín, M.B. La relación clima-turismo: Consideraciones básicas en los fundamentos teóricos y prácticos. Investigaciones Geográficas 1999, 21, 21-34. [CrossRef]

3. Gómez, M.B. Reflexión geográfica en torno al binomio clima-turismo. Boletín de la AGE 2005, 40, 111-134.

4. Faulkner, B.; Vikulov, S. Katherine, washed out one day, back on track the next: A post-mortem of a tourism disaster. Tour. Manag. 2001, 22, 331-344. [CrossRef]

5. Wong, P. Coastal tourism development in Southeast Asia: Relevance and lessons for coastal zone management. Ocean Coast. Manag. 1998, 38, 89-109. [CrossRef]

6. Vera Rebollo, F.; Treviño Pérez, A. Transformaciones antrópicas e inundabilidad en áreas turísticas litorales: Estudio de caso de la costa de Orihuela (Alicante). Papeles de Geografía 2010, 51-52, 317-326.

7. Kellens, W.; Neutens, T.; Deckers, P.; Reyns, J.; De Maeyer, P. Coastal flood risks and seasonal tourism: Analysing the effects of tourism dynamics on casualty calculations. Nat. Hazards 2012, 60, 1211-1229. [CrossRef]

8. Frihy, E. The necessity of environmental impact assessment (EIA) in implementing coastal projects: Lessons learned from the Egyptian Mediterranean Coast. Ocean Coast. Manag. 2001, 44, 489-516. [CrossRef]

9. Gu, M.; Wong, P. Coastal zone management focusing on coastal tourism in a transitional period of China. Ocean Coast. Manag. 2008, 51,1-24. [CrossRef]

10. Becken, S. Harmonising climate change adaptation and mitigation: The case of tourist resorts in Fiji. Glob. Environ. Chang. 2005, 15, 381-393. [CrossRef]

11. Petzold, J.; Ratter, B. Climate change adaptation under a social capital approach. An analytical framework for small islands. Ocean Coast. Manag. 2015, 112, 36-43. [CrossRef] 
12. European Environment Agency. Urban Adaptation to Climate Change in Europe: Challenges and Opportunities for Cities. Together with Supportive National and European Policies; European Commission: Copenhagen, Denmark, 2013; p. 148.

13. Ministerio de Medioambiente. Impactos en la Costa Española por Efecto del Cambio Climático; Fase III; Estrategias frente al cambio climático en la costa: Madrid, Spain, 2014; p. 132.

14. Camarasa, A.M.; Segura, F. Las crecidas en ramblas valencianas mediterráneas. Estudios Geográficos 2001, 62, 649-667. [CrossRef]

15. Conesa-García, C.; García, E.X. Las áreas históricas de inundación en Cartagena. Boletín de la AGE 2003, 35, 79-100.

16. Giménez-Ferrer, J. Riesgo de inundación y ordenación territorial: El caso de la ley valenciana 4/2004. Observatorio Medioambiental 2007, 10, 145-177.

17. Gómez, M.B. Retos del turismo español ante el cambio climático. Investigaciones Geográficas 2017, 67, 31-47.

18. UNWTO. UNWTO Annual Report 2018; UNWTO: Madrid, Spain, 2008; p. 20.

19. Instituto Canario de Estadística. ISTAC; Annual Statistics: Tenerife, Spain, 2018.

20. IMPACTUR. Estudio del Impacto Económico del Turismo Sobre la Economía y el Empleo de las Islas Canarias; Exceltur and Gobierno de Canarias: Madrid, Spain, 2017; p. 38.

21. Alianza Para la Excelencia Turística (EXELTUR). 2018. Available online: https://www.exceltur.org/ (accessed on 13 December 2019).

22. Cropper, T.; Hanna, E. An analysis of the climate of Macaronesia, 1865-2012. Int. J. Climatol. 2014, 34, 604-622. [CrossRef]

23. Alexanderson, H. A homogeneity test applied to precipitation data. Int. J. Climatol. 1986, 6, 661-675. [CrossRef]

24. Pettitt, A. A nonparametric approach to the change-point problem. J. R. Stat. Soc. 1979, 28, 126-135.

25. Buishand, T. Some methods for testing the homogeneity of rainfall records. J. Hydrol. 1982, 58, 11-27. [CrossRef]

26. Dorta, P. Catálogo de riesgos climáticos en Canarias: Amenaza y vulnerabilidad. Geogaphicalia 2007, 51, 133-160.

27. Máyer, P.; Marzol, M.V.; Parreño, J.M. Precipitation trends and a daily precipitation concentration index for the mid-eastern Atlantic (Canary Islands, Spain). Cuadernos de Investigaciones Geográficas 2017, 43, 255-268. [CrossRef]

28. Jenkinson, A.; Collison, F. An initial climatology of gales over the North Sea. Synoptic Climatology Branch Memorandum. Meteorol. Off. 1977, 1-62.

29. Jones, P.; Hulme, M.; Briffa, K. A comparison of Lamb circulation types with an objective classification scheme. Int. J. Climatol. 1993, 13, 655-663. [CrossRef]

30. Lamb, H. British Isles weather types and a register of daily sequence of circulation patterns, 1861-1971. Geophys. Memoir. 1972, 116, 1-85.

31. Spellman, G. The application of an objective weather-typing system to the Iberian Peninsula. Weather 2000, 55, 375-385. [CrossRef]

32. Trigo, R.; DaCamara, C. Circulation weather types and their influence on the precipitation regime in Portugal. Int. J. Climatol. 2000, 20, 1559-1581. [CrossRef]

33. Llop, J.; Alomar, P. Clasificación sinóptica automática de Jenkinson y Collison para los días de precipitación mayor o igual a $100 \mathrm{~mm}$ en la franja litoral catalana e Islas Baleares. Territoris 2012, 8, 143-152.

34. Grimalt, M.; Tomás, M.; Alomar, G. Determination of the Jenkinson and Collinson's weather types for the western Mediterranean basin over the 1948-2009 period. Temporal analysis. Atmósfera 2013, 26, 75-94. [CrossRef]

35. Chen, D. A monthly circulation climatology for Sweden and its application to a winter temperature case study. Int. J. Climatol. 2000, 20, 1067-1076. [CrossRef]

36. Tang, L.; Chen, D.; Karlsson, P.-E.; Gu, Y.; Ou, T. Synoptic Circulation and its influence on spring and summer surface ozone concentrations in southern Sweden. Boreal Environ. Res. 2009, 14, 889-902.

37. Linderson, M. Objective classification of atmospheric circulation over southern Scandinavia. Int. J. Climatol. 2001, 21, 155-169. [CrossRef]

38. Post, P.; Truija, V.; Tuulik, J. Circulation weather types and their influence on temperature and precipitation in Estonia. Boreal Environ. Res. 2002, 7, 281-289. 
39. Spellman, G. An assessment of the Jenkinson and Collison synoptic classification to a continental mid-latitude location. Theor. Appl. Climatol. 2017, 128, 731-744. [CrossRef]

40. Sarricoela, P.; Meseguer-Ruiz, O.; Martín Vide, J. Variabilidad y tendencias climáticas en Chile central en el período 1950-2010 mediante la determinación de los tipos sinópticos de Jenkinson y Collison. Boletín de la AGE 2014, 64, 227-247.

41. Daily Northern Hemisphere Sea Level Pressure Grids, Continuing from 1899. Available online: https: //rda.ucar.edu/datasets/ds010.0/ (accessed on 29 October 2019).

42. Kozanis, S.; Christofides, A.; Namassis, N.; Efstratiadis, A.; Koutsoyiannis, D. Hydrognomon-Open source software for the analysis of hydrological data. In Proceedings of the European Geosciences Union (EGU) General Assembly, Vienna, Austria, 2-7 May 2010.

43. Pita, M.F. El papel de la prensa en el studio de las sequías. In IX Coloquio de Geógrafos Españoles; Tomo, I., Ed.; Asociación de Geógrafos Españoles: Murcia, Spain, 1985.

44. Parreño, J.M. El proceso de urbanización del espacio turístico. In Evolución e Implicaciones del Turismo en Maspalomas Costa Canaria; Hernández-Luis, J.A., Parreño, J.M. (coord), Tomo, I., Eds.; Ayuntamiento de San Bartolomé de Tirajana: Las Palmas, Spain, 2001.

45. García-Cruz, J.I. El Impacto Territorial del Tercer Boom Turístico de Canarias; Servicio de Publicaciones de la Universidad de La Laguna: San Cristóbal de La Laguna, Spain, 2013.

46. Marzol, M.V. La Lluvia, un Recurso Natural Para Canarias; Caja Canarias: Santa Cruz de Tenerife, Spain, 1988.

47. Luque, A.; Martín, J.; Dorta, P.; Mayer, P. Temperature trends on Gran Canaria (Canary Islands). An example of global warming over the subtropical Northeastern Atlantic. Atmos. Clim. Sci. 2014, 4, 20-28. [CrossRef]

48. Marzol, M.V. La incidencia de las sequías en las Canarias Occidentales y Orientales. In Causas y consecuencias de las sequías en España; Gil-Olcina, A., Morales Gil, A., Eds.; Universidad de Alicante: Alicante, Spain, 2001; pp. 345-371.

49. Máyer, P.; Marzol, M.V. Algunas reflexiones acerca del clima de las islas Canarias. Nimbus 2012, 29, 399-416.

50. Máyer, P.; Marzol, M.V. La concentración pluviométrica diaria y las secuencias lluviosas en Canarias: Dos factores de peligrosidad. Boletín de la AGE 2014, 65, 231-247.

51. Martín-Vide, J. El Tiempo y el Clima; Rubes: Barcelona, Spain, 2003; p. 128.

52. Lemus, M.; López-Bustins, J.A. Variabilidad espacio temporal de la precipitación en el sur de Cataluña y su relación con la oscilación del Mediterráneos Occidental (WEMO). In Clima, Sociedad, Riesgos y Ordenación del Territorio; Olcina, J., Rico, A., Moltó, E., Eds.; Alicante, Instituto Interuniversitario de Geografía, Universidad de Alicante: Alicante, Spain, 2016; pp. 225-236.

53. Máyer, P.; Chacón, E. Tourist activity and floods on the southern coast of Gran Canaria. An indices risk? J. Coast. Res. 2006, 48, 77-80.

54. Martín-Vide, J. Spatial distribution of a daily precipitation concentration index in Peninsular Spain. Int. J. Climatol. 2004, 24, 959-971. [CrossRef]

55. Marzol, M.V. Lluvias e inundaciones en la ciudad de Santa Cruz de Tenerife. In El Agua y el Clima; Guijarro, J.A., Grimalt, M., Laita, M., Alonso, S., Eds.; Asociación Española de Climatología (AEC): Palma de Mallorca, Spain, 2002; pp. 36-42.

56. Máyer, P. Desarrollo urbano e inundaciones en la ciudad de Las Palmas de Gran Canaria (1869-2000). Investigaciones Geográficas 2002, 28, 145-159. [CrossRef]

57. Cantos, J.O. Riesgos de inundaciones y ordenación del territorio en la escala local: El papel del planeamiento municipal. Boletín de la AGE 2004, 37, 49-84.

58. Tarife, R.; Hernández, S.; Gámiz, S.; Castro, Y.; Esteban, M. Análisis de los extremos pluviométricos en las islas Canarias y su relación con el índice NAO. In Proceedings of the VIII Congreso Internacional AEC, Salamanca, Spain, 25-28 September 2012.

(C) 2019 by the authors. Licensee MDPI, Basel, Switzerland. This article is an open access article distributed under the terms and conditions of the Creative Commons Attribution (CC BY) license (http://creativecommons.org/licenses/by/4.0/). 